\title{
¿Increasing Warm-Season Precipitation in Asian Drylands and Response to Reducing Spring Snow Cover over the Tibetan Plateau
}

\author{
Jie Zhang, ${ }^{a}$ Qianrong Ma, ${ }^{a}$ Haishan Chen, ${ }^{a}$ Siwen Zhao, ${ }^{\mathrm{b}}$ And Zhineng Chen ${ }^{\mathrm{a}}$ \\ ${ }^{a}$ Key Laboratory of Meteorological Disaster, Ministry of Education/Joint International Research Laboratory of Climate and \\ Environment Change/Collaborative Innovation Center on Forecast and Evaluation of Meteorological Disasters, \\ Nanjing University of Information Science and Technology, Nanjing, China \\ ${ }^{\mathrm{b}}$ Institute of Atmospheric Environment, China Meteorological Administration, Shenyang, China
}

(Manuscript received 26 June 2020, in final form 18 November 2020)

\begin{abstract}
Precipitation is crucial for life and the ecological environment in Asian drylands. This study investigated precipitation trends in Asian drylands in the previous four decades and simulated their possible linkage with snow cover reduction over the Tibetan Plateau. The results show that precipitation has been increasing and contributing to wetter conditions in Asian drylands. The increasing trends can be attributed to the deepened quasi-stationary wave trough around Lake Balkhash and the meridional water vapor flux originating from the Arabian Sea and the Bay of Bengal. The midlatitude waves and eddy disturbances correspond to the northward upper-level Tibetan Plateau (TP) mode of the South Asian high (TP-SAH) and the Afro-Asian jet with cyclonic rotation. Both SAH and Afro-Asian jet anomalies strengthen the ascending motion and northward water vapor convergence in Asian drylands, and those are favorable for summer precipitation. The anomalous circulations are linked to the following factors. First, the reduced snow cover (SC) over the west TP in the late spring results in decreasing soil moisture and increasing diabatic heating in summer and favors northward extension of TP-SAH and the Afro-Asian jet. Second, the reduced TP SC increases surface temperature over the TP and northeast Asia, which decreases the temperature gradient between the TP and the Indian Ocean, between northeast Asia and East Asia. Decreased temperature gradients are beneficial to the southwest-northeast cyclonic rotation of the Afro-Asian jet and consequently strengthen the southerly wind and northward water vapor flux over the TP and surrounding regions. This study emphasizes important effects of the reducing TP SC on intensifying summer precipitation in Asian drylands.
\end{abstract}

KEYWORDS: Atmosphere-land interaction; Snow cover; Climate change; Diabatic heating

\section{Introduction}

Drylands cover more than $40 \%$ of global land and sustain about $38 \%$ of the global population. In particular, Asian drylands comprise one of the largest nonzonal extratropical arid and semiarid regions in the world, spanning approximately $45^{\circ}-115^{\circ} \mathrm{E}$ and $35^{\circ}-$ $55^{\circ} \mathrm{N}$ and including central Asia, the northwest area of East Asia, Mongolia, and parts of western Asia (Huang et al. 2016). Asian drylands have a unique ecological pattern, with the land cover types varying from grass-covered steppe to sand dunes and gravel (Baldwin and Vecchi 2016). They are characterized as having severe water shortages and fragile ecosystems.

Asian drylands are extraordinarily sensitive to climate change (Lioubimtseva and Henebry 2009). Over the past century, the effect of global warming in drylands $\left(1.2^{\circ}-1.3^{\circ} \mathrm{C}\right)$ has been $20 \%-40 \%$ higher than that in humid lands $\left(0.8^{\circ}-\right.$ $1.0^{\circ} \mathrm{C}$ ). Moreover, it will reach $3^{\circ} \mathrm{C}$ under the projected future global warming of $1.5^{\circ}$ (Huang et al. 2017). Among the adverse effects of global warming, water shortage is the most serious threat to Asian drylands (Howard and Howard 2016; Huang et al. 2017) because it puts such regions at high risk of land

\footnotetext{
D Denotes content that is immediately available upon publication as open access.
}

Corresponding author: Jie Zhang, gs-zhangjie@163.com; zhangj @ nuist.edu.cn degradation and desertification (Safriel 2009). Therefore, with drylands being a trade route for the ancient Silk Road and the new Silk Road Economic Belt (Christian 2000; Frachetti et al. 2017), dryland water resources have attracted significant attention (M. Chen et al. 2008; Chen and Chen 2012; Bothe et al. 2012; Huang et al. 2013). Hence, it is worth exploring how Asian drylands develop in the background of global warming.

Previous studies have shown that most Asian drylands have been experiencing warm and wet conditions since the 1980s (Shi et al. 2003). Their main water supply is from melting glaciers (Pritchard 2019), increasing runoff (Hagg et al. 2007; Sorg et al. 2012; Huss and Hock 2018), expanding lake areas (Wan et al. 2016), and intensified precipitation (Andrews 2010; Deng et al. 2015; Hong et al. 2015; Xue et al. 2017), which further promote greening vegetation (Rosenberg et al. 1989; Douville et al. 2013). As the main water tower of central Asia and East Asia, the Tianshan Mountains, the Tibetan Plateau (TP), and the Pamir Plateau provide the main water resources for Asian drylands in the form of glacier and snow water (Chen et al. 2016; Wang and Zhang 2019; Yao et al. 2019). Zhang et al. (2011) suggested that climate change accelerates glacier or snow melting and runoff, with a decrease in glacier or snow water storage at the rate of $-3.72 \mathrm{~mm} \mathrm{yr}^{-1}$ from 2003 to 2014 . Glacier melting water will decrease in the long term under the continuous warming and current precipitation conditions, and thereby lead to lake shrinkage and water supply deficit in Asian drylands. Yao et al. (2018) found that lake shrinkage had distinctly aggravated drought in Xinjiang from 1961 to 2015. In 
addition, Li et al. (2017) found a drying trend over central Asia from 2000 to 2014. These findings indicate that Asian drylands are facing water resources stress due to decreasing ice/ snow water.

Precipitation in the mountains and local regions is one of the major water sources for Asian drylands. Previous studies have shown that increasing precipitation has been observed over northwestern China and arid Xinjiang, and increasing extreme precipitation predominantly contributes to the total rainfall (Chen et al. 2014; Huang et al. 2015; Xu et al. 2015; M. Zhang et al. 2017; Wang et al. 2018; Zhang et al. 2019). For instance, in 1979-2018, the total summer precipitation over central Asia significantly increased (Bothe et al. 2012). However, the period of increasing precipitation is still unclear, and it is unknown whether increasing precipitation ameliorates the effect of the decreasing water supply due to glacier shrinkage along with global warming. The primary cause of precipitation anomaly is yet to be determined.

Precipitation-related circulation is vital for addressing these issues. Precipitation in Asian drylands relates to internal dynamic processes, including the magnitude of the amplitude of Rossby waves (Zhang et al. 2020), the anomalous wave trough over Lake Balkhash, and the South Asian high (SAH). In addition, it is highly likely that the westerly jet stream is linked with the precipitation over central Asia (F. Chen et al. 2008; Bothe et al. 2012). Circulation anomalies usually correlate with external forcing such as solar forcing, volcanic eruptions, sulfate aerosols, and greenhouse gases (Yang et al. 2004; Zhang et al. 2020). Different anomalies of sea surface temperature (SST) patterns mixed with greenhouse gases are the most important type of forcing (Huang et al. 2016; Xie et al. 2010). The summer extreme precipitation in northern Xinjiang is likely related to the water vapor transport from the North Atlantic Ocean and the Indian Ocean (Huang et al. 2017). Gerlitz et al. (2019) suggested that El Niño enhanced the water vapor supply from the Arabian Sea to central Asia via the Hadley cell. The Eurasian snow cover in the preceding autumn influenced the wintertime Arctic Oscillation and the Northern Hemispheric Rossby wave trough over central Asia and led to more precipitation. However, there is limited research on the precipitation in those drylands and related forcing beyond the interannual time scale. Therefore, it is necessary to determine whether the increased precipitation will remain for a long period and to identify the link between forcing on the multidecadal time scale and trend, which is significant for the development of Asian drylands.

Considering the sequential dryland warming and intensive snow/ice melting and water loss, it is crucial to understand precipitation variability and its contribution to the water supply and development of Asian drylands. In addition, the possible mechanisms of the effects of decreasing snow cover on precipitation change on the multidecadal time scale and trends in Asian drylands should be clarified.

The remainder of this study is organized as follows. In section 2, the datasets, analytical methods, and models are introduced. In section 3, the impacts of the decreasing spring snow cover over TP on warm-season precipitation in Asian drylands are analyzed. In section 4 , the study is summarized and concluded.

\section{Data and methods}

\section{a. Data sources}

The daily precipitation data used in this study were obtained from the National Oceanic and Atmosphere Administration (NOAA) Climate Prediction Center (CPC) (https://climatedataguide.ucar.edu/ climate-data/cpc-unified-gauge-based-analysis-global-dailyprecipitation). The precipitation data have a horizontal resolution of $0.25^{\circ} \times 0.25^{\circ}$ over Asian drylands $\left(10^{\circ}-60^{\circ} \mathrm{N}\right.$, $\left.45^{\circ}-110^{\circ} \mathrm{E}\right)$ and are unified by satellite and rain gauge data (M. Chen et al. 2008; Xie et al. 2007). Continuous daily precipitation data for 1979-2018 were selected.

To understand the impact factors of precipitation in Asian drylands, the European Centre for Medium-Range Weather Forecasts (ECMWF) reanalysis (ERA-Interim) dataset was utilized (Dee et al. 2011). This dataset was improved by water vapor analysis and satellite data error correction technology (Hodges et al. 2011). The data have a horizontal resolution of $0.75^{\circ} \times 0.75^{\circ}$ with four-dimensional variation and were obtained from http://apps.ecmwf.int/datasets/. The geopotential height, wind velocity at $500 \mathrm{hPa}$, and water vapor-related parameters from all pressure levels were used for circulation and water vapor transport analysis.

The snow cover over the west $\mathrm{TP}\left(70^{\circ}-90^{\circ} \mathrm{E}, 31^{\circ}-41^{\circ} \mathrm{N}\right)$ in the later spring and early summer (April-June) from 1966 to 2015 was obtained from the Global Snow Laboratory at Rutgers University (http://climate.rutgers.edu/snowcover), with a polar stereographic projection of the Northern Hemisphere and $89^{\circ} \times 89^{\circ}$ grid (Estilow et al. 2015). Long-term monthly sea surface temperatures from 1950 to 2019 were obtained from the Met Office Hadley Centre website (https:/www.metoffice.gov.uk/ hadobs/; HadISST data). The climatological SST dataset was used to simulate and eliminate the SST effect on precipitation; the period of the SST dataset was close to one period (65-80 years) of Atlantic multidecadal variability and one period (50-70 years) of Pacific decadal oscillations (Minobe 1997).

Water vapor flux from the surface to $300 \mathrm{hPa}$ from different profiles was defined as zonal QuW when it was via the west boundary $\left(35^{\circ}-50^{\circ} \mathrm{N}\right.$ along $\left.53^{\circ}-55^{\circ} \mathrm{E}\right)$, and meridional QvN when it was via the north boundary $\left(60^{\circ}-70^{\circ} \mathrm{E}\right.$ along $\left.52^{\circ}-55^{\circ} \mathrm{N}\right)$. Meridional water vapor flux via the south boundary along the $30^{\circ}-32^{\circ} \mathrm{N}$ profile was defined as QvW, QvM, and QvE when it was from the west $\left(65^{\circ}-70^{\circ} \mathrm{E}\right)$, middle $\left(65^{\circ}-72^{\circ} \mathrm{E}\right)$, and east $\left(95^{\circ}-105^{\circ} \mathrm{E}\right)$, respectively.

\section{b. Statistical analyses}

The transient eddy is the difference between the anomaly of zonal mean meteorological field and the standing vortex. To validate the weather-scale transient waves, transient $U$ and $V$ were obtained for the 2.5-6 days by a bandpass filtering technique at $200 \mathrm{hPa}$ on the whole latitude belt. They were used to calculate water vapor flux. Empirical orthogonal function analysis was employed to display the spatial and temporal patterns of 500-hPa $U$ and $V$ wind and geopotential height. The statistical significance of the linear regression coefficient, anomaly field, and the correlation between two series were assessed using a two-tailed Student's $t$ test and Monte Carlo test. The correlations were obtained from the original series with an effective freedom of 40 years (1979-2018). 


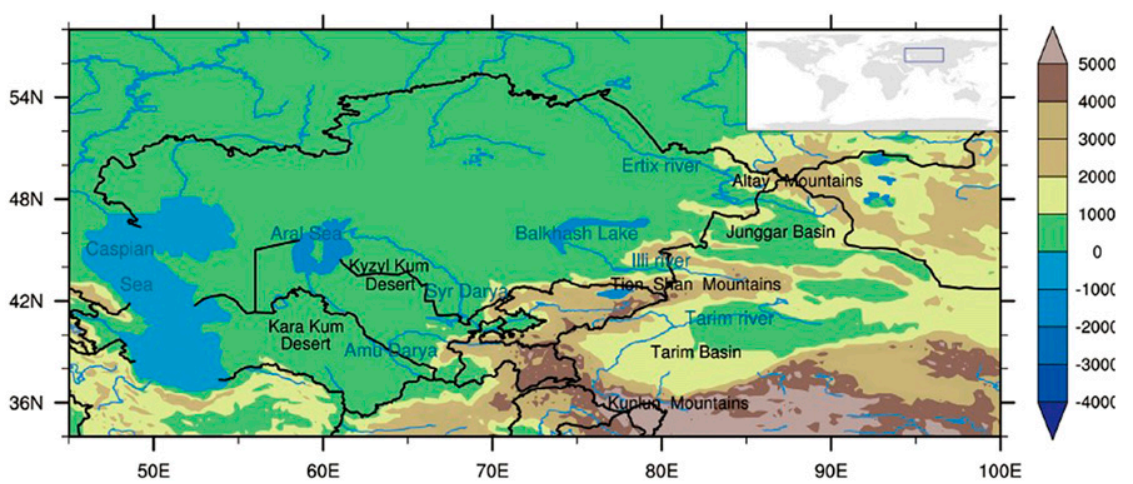

FIG. 1. Position of Asian drylands and its topography.

\section{c. Models}

The Hybrid Single Particle Lagrangian Integrated Trajectory (HYSPLIT; https://ready.arl.noaa.gov/HYSPLIT.php) model was used to perform simple water vapor, particle transport, and deposition simulations (Stein et al. 2015). The HYSPLIT trajectory is widely used in investigating water vapor trajectories with backward trajectory directions. To overcome the uncertainty, Lagrangian trajectory, and water vapor release as rainfall prior to its arrival at the target position, the present study verified the effectiveness of Lagrangian trajectory using the method from Sodemann et al. (2008) and Huang et al. (2018).

The Community Earth System Model (CESM1.0; Hurrell et al. 2013) developed by the National Center for Atmospheric Research (NCAR) consists of interactively coupled models for the atmosphere (CAM), ocean (POP), land (CLM), and sea ice (CICE). The model components are available at http://www. cesm.ucar.edu/models/cesm1.0/. The model is used to investigate the effects of the snow cover on the summertime circulation and precipitation. The atmospheric component is the Community Atmospheric Model version 5.1 (CAM5.1), including a finite volume dynamic framework with a horizontal resolution of $1.9^{\circ} \times 2.5^{\circ}$ and 30 vertical layers of the $\sigma-p$ vertical coordinates.

The snow cover in the late spring and early summer affects the circulation and summer precipitation (Zhang et al. 2018a). It has reduced with global warming because temperature drives precipitation shifts from snow to rain, earlier melting of the snowpacks, and an earlier end of the snow season (Barnett et al. 2005). In the sensitivity experiments, the snow cover was reduced by $30 \%$ by removing snow cover in those pixels with less snow depth over the edge of objects from April to June. It reflects the decreasing snow cover and is close to the current snow/ice reduction of approximately $15 \%$, which represents the warm anomaly after 2000 (Qiu 2012; http://www.china.org.cn/ environment/2014-05/22/content_32456939.htm). The climatological SST data from 1950 to 2019 were used in the simulation. Both the sensitivity and control experiments were operated for 20 years with daily output variables. The snow cover in the sensitivity simulation was changed in every year and the model was restarted.

\section{Results}

\section{a. Precipitation variation characteristics}

Asian drylands are one of the largest arid and semiarid regions. They are located in the hinterlands of Eurasia and farther into the extratropical regions than any other major drylands (Fig. 1). In this study, the Asian dryland region encompasses central Asia and the northwestern areas of East Asia, including Kazakhstan, Uzbekistan, Turkmenistan, Tajikistan, Kyrgyzstan, the northern TP, northwest China, and western Mongolia (M. Zhang et al. 2017). This work mainly focuses on the region $45^{\circ}-96^{\circ} \mathrm{E}, 35^{\circ}-55^{\circ} \mathrm{N}$, covering an area of approximately 5.65 million $\mathrm{km}^{2}$ (Zhang et al. 2019).

The seasonal precipitation trends in Asian drylands are illustrated in Fig. 2. The results show that seasonal precipitation varies in the different regions in the Asian drylands and the surrounding regions. Precipitation significantly increased around Lake Balkhash in all seasons, particularly from Lake Balkhash to the Tianshan Mountains. Given that high mountains act as the water tower of Asian drylands, precipitation changes in those regions have garnered significant attention worldwide, making drylands a key region for Asian climate (Karl and Trenberth 2003). Precipitation also significantly increased in the northern TP in spring, summer, and autumn. The interior rivers, such as the Heihe and Shiyang Rivers, originate in the TP and create an oasis in the arid region in northwest China (Li et al. 2018). In addition, a weak increasing trend of precipitation was observed for all seasons in northwest China. Thus, it is critical to understand the variability of the circulation and water vapor flux in Asian drylands.

\section{b. Precipitation-related circulation anomalies}

To reveal the cause of intensified precipitation, which is mainly attributed to heavy rain (Jiang et al. 2020), all heavy rain cases with daily precipitation exceeding $6 \mathrm{~mm}$ in central Asia were selected. The composite data were further analyzed. The first four leading circulation modes had a variance of $46.7 \%, 21.8 \%, 11.7 \%$, and $5.6 \%$, respectively, and the total variance reached $85 \%$. Subsequently, four regions in Asian drylands were plotted based on the four cyclonic modes and 

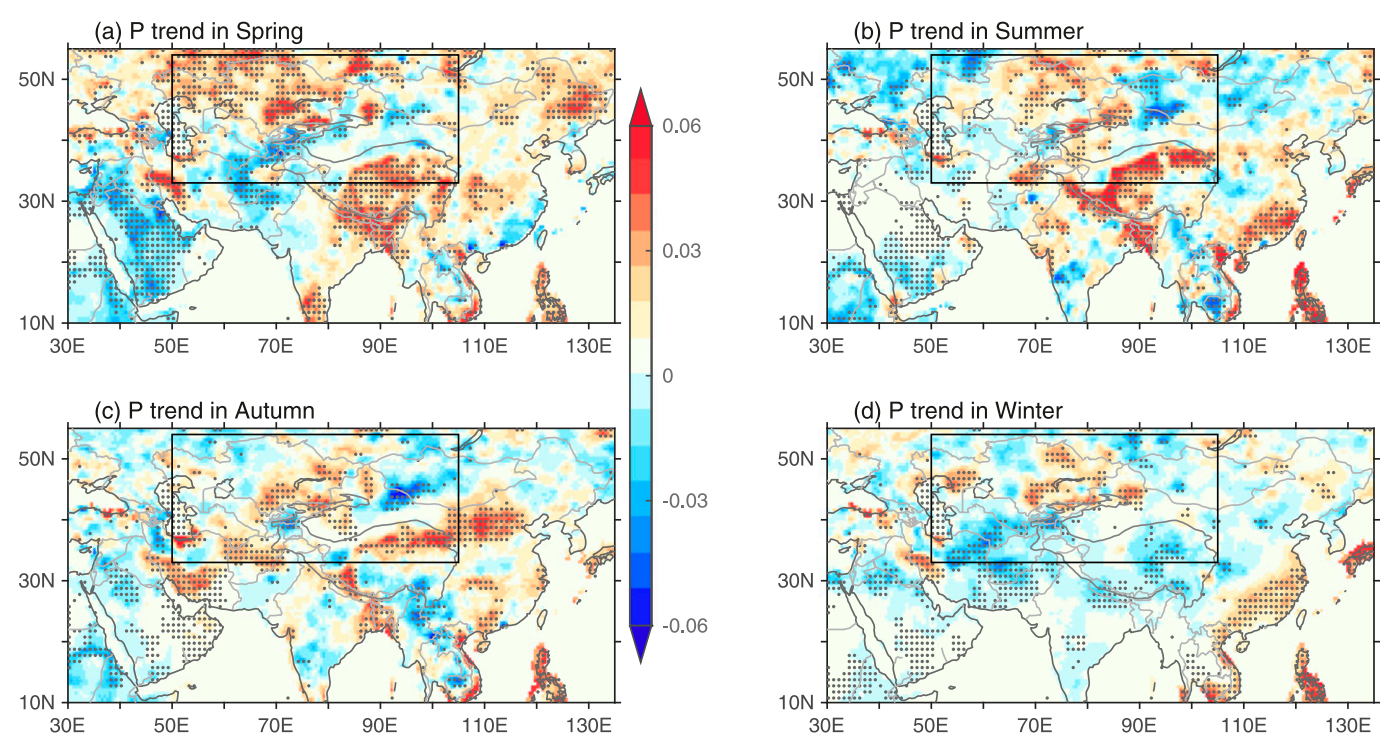

FIG. 2. Seasonal precipitation trend in Asian drylands (black boxes) and surrounding regions. Dots indicate the $95 \%$ significant confidence level, and the black box indicates the region of the Asian drylands investigated in this study.

the topography distribution. The regression results of $500-\mathrm{hPa}$ geopotential height and $U$ and $V$ wind field to those four principal components (PCs) are displayed in Fig. 3.

The first pattern (Fig. 3a1) reflects an enhanced cyclone on the planetary spatial scale that strengthens the quasi-stationary wave trough over Lake Balkhash. The anticyclonic anomaly over the west of Ural Mountains strengthens the quasistationary wave ridge in the eastern Europe. This pattern indicates an enhanced meridional circulation, and the PC1 series shows the decadal variation of the circulation. The second pattern (Fig. 3b1) reflects an enhanced cyclone on the north of TP to Lake Baikal. It is similar to a negative-phase east Atlantic/western Russia pattern (EA/WR; Lim 2015), which is one of the three prominent teleconnection patterns affecting Eurasia, and the enhanced cyclone is also a response to the Arctic ice loss and North Atlantic SST pattern (Okumura et al. 2001). The PC2 series shows an interannual variation of the teleconnection. The third pattern (Fig. 3c1) exhibits an enhanced cyclone on the western TP to the Tianshan Mountains, which corresponds to the midlatitude Silk Road Pattern (SRP; Enomoto 2004) propagating along the subtropical jet stream (Ding and Wang 2005; J. Zhang et al. 2017) and the highlatitude Eurasian (EU) teleconnections (Lim and Kim 2013; Liu et al. 2014). The series of PC3 shows an interdecadal variation of enhanced SRP after 2000, which benefits the cyclonic anomaly over the TP and Tianshan Mountains. The fourth pattern (Fig. 3d1) reflects an enhanced cyclone anomaly over the South Asian drylands, and the PC4 series has interannual variations. Using a 1.2 multiple standard deviation of four PCs, more than 20 cases were selected for each PC. A composite 500-hPa geopotential height and wind field (Figs. 3a2-d2) was prepared in accordance with the regression distribution (Figs. 3a1-d1). It also represents the heavy rain events corresponding to four regions, indicating that four synoptic patterns could represent circulation anomalies of four regions. Figure 3 reveals the anomaly of large-scale circulation on an interannual to decadal time scale exhibiting cyclonic anomalies and ascending motion in the four regions that favor precipitation in the Asian drylands. In addition, these circulation anomalies are beneficial for water vapor convergence.

\section{c. Precipitation-related water vapor}

The precipitation anomalies in these regions also reflect the variability of water vapor transport and water vapor sources (Schiemann et al. 2009; Linderholm et al. 2011). Figure 4 shows the regressed $500-\mathrm{hPa}$ water vapor flux and water vapor divergence against four types of synoptic circulations, which reveals the different water vapor transport pathways in Asian drylands. As shown in Fig. 4a, three water vapor pathways are present in Asian drylands according to climatological water vapor flux and the four modes. The first water vapor pathway (blue arrow line) starts at the northern boundary of Asian drylands, where water vapor originates from the Caspian, Aral, Mediterranean, and Black Seas and the Atlantic Ocean. It follows the westerlies and quasi-stationary wave ridge (Fig. 4). In addition, the water vapor transport from the northern boundary also originates from the Arctic Sea (blue arrow line in Figs. 4a-d) along with the EU pattern. The water vapor transport (light green arrow line in Figs. 4a,d) from the western boundary follows the prevailing westerlies (Huang et al. 2013; Yatagai 2003) and originates from the Mediterranean Sea, Atlantic Ocean, and Caspian Sea. Moreover, there are three water vapor pathways from the southern boundary. The first pathway (dark green arrow line in Figs. 4a,b) originates from the Arabian Sea toward the north and northeast, and it influences most of the Asian drylands. Moreover, it is accompanied by an anticyclone over the northeast Indian subcontinent and a deep trough over Lake Balkhash (Fig. 2). The second pathway 
(a1) Regression of 500-hPa Z/UV to PC1

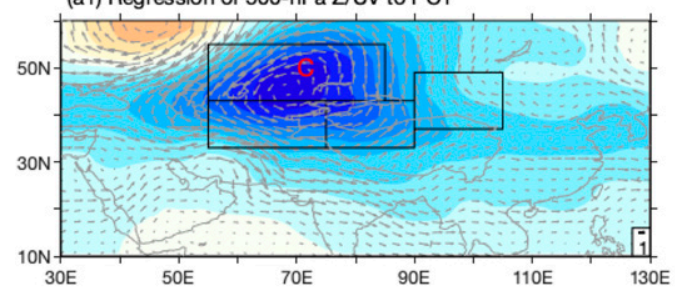

(b1) Regression of 500-hPa Z/UV to PC2

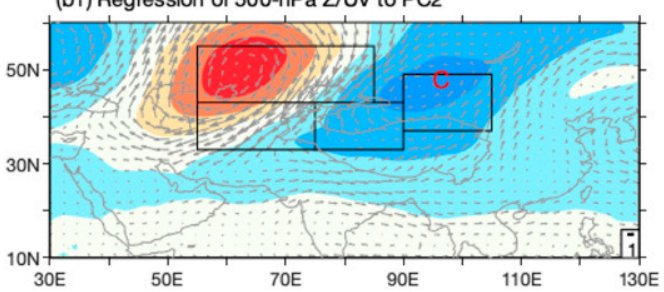

(c1) Regression of 500-hPa Z/UV to PC3

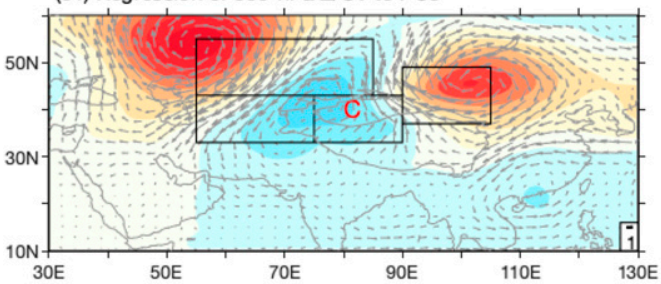

(d1) Regression of 500-hPa Z/UV to PC4

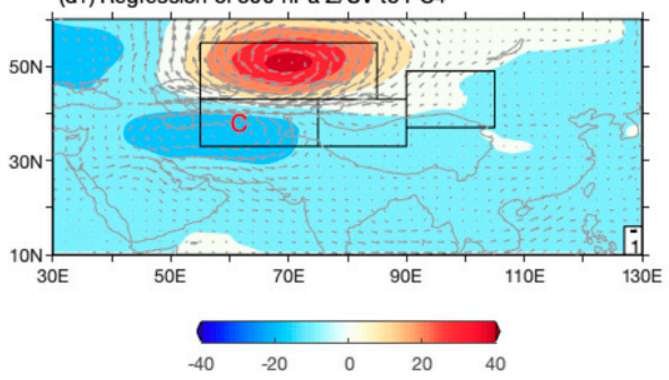

(a2) Composite 500-hPa Z/UV of PC1>1.2 Std.

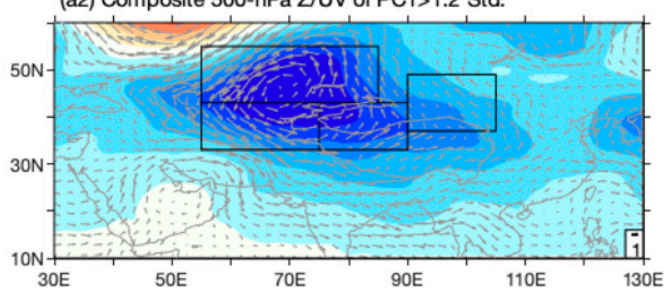

(b2) Composite 500-hPa Z/UV of PC2>1.2 Std.

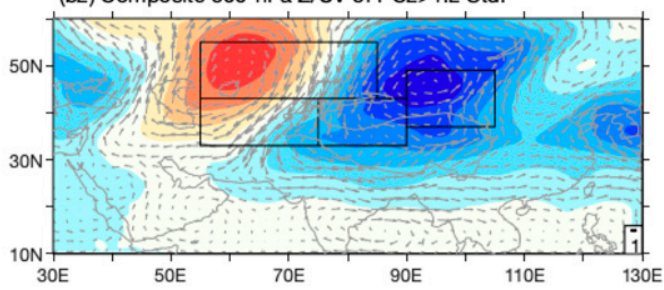

(c2) Composite 500-hPa Z/UV of PC3>1.2 Std.

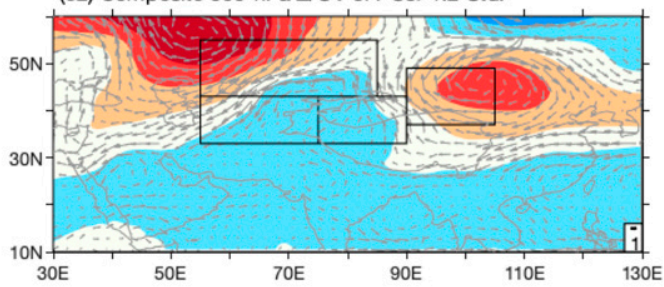

(d2) Composite 500-hPa Z/UV of PC4>1.2 Std.

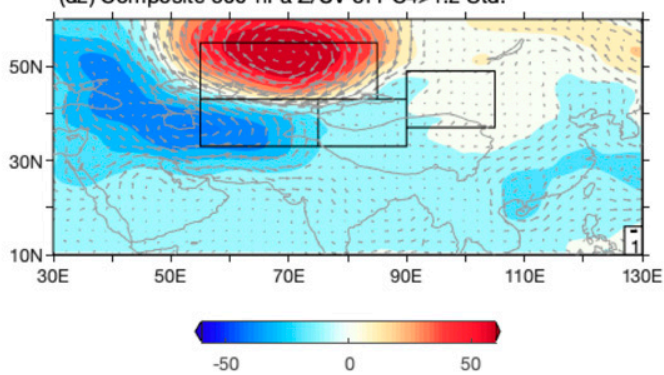

FIG. 3. Regression of 500-hPa geopotential height and $U$ and $V$ wind to PCs of (a1)-(d1) four types of synoptic circulation, and (a2)-(d2) the composite 500-hPa geopotential height and $U$ and $V$ wind of those PCs $>1.2$ standard deviation (Std.). Black boxes show the four selected regions in Asian drylands. The letter $\mathrm{C}$ marks a cyclone anomaly.

(pink arrow line in Figs. 4c,d) originates from the Bay of Bengal toward the northwest and western TP, creating a cyclone over the north Indian Ocean and an anticyclone over eastern TP. The third pathway (pink arrow line in Figs. 4a,b) also originates from the Bay of Bengal but toward the eastern TP following a cyclone over the TP, which is one of the important water vapor transport pathways for northwest China (Romatschke and Houze 2011). Over Asian drylands, the quasi-stationary water vapor transport is responsible for the anomalous water vapor convergence in summer. It is also associated with teleconnection pattern. The anticyclonic centers are located to the north of the Caspian Sea. The cyclonic center deepens the trough around Lake Balkhash that transfers water vapor from the western and northern boundaries. The southwest flow in front of the wave trough along with the Indian anticyclone and TP cyclone enhances the northward water vapor transport (Fig. 4).

Using the backward trajectory simulation of the HYSPLIT model (Fig. 5), water vapor transport pathways and the contribution rates in summer in 2017 and 2019 were investigated at four positions representing the four regions (Fig. 4). The results show that water vapor transports in different regions are not consistent and can be summarized as five water vapor transport branches. The westerly water vapor pathway originates from the Atlantic Ocean and the Mediterranean and Caspian Seas and enters the Asian drylands from the western and northern boundaries, and the water vapor branch appears in all regions. Water vapor from the northern boundary also originates from Atlantic and Arctic Oceans through the EU pattern and influences the western (lower-left panel) and northern regions 
(a) Regression of Qdiv/Quv to PC1

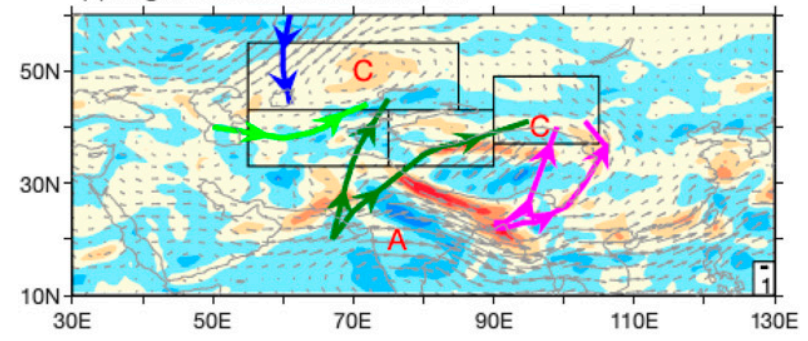

(b) Regression of Qdiv/Quv to PC2

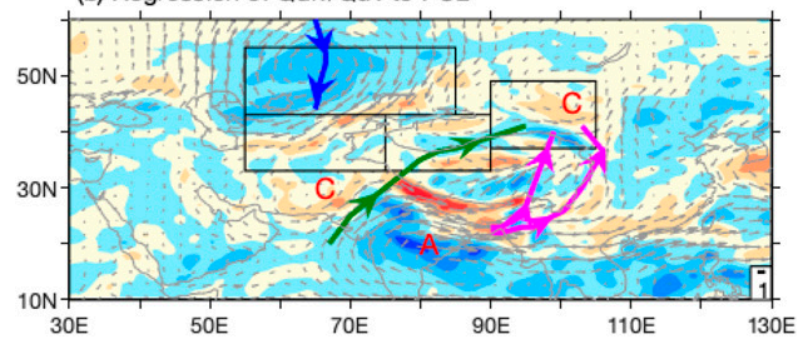

(c) Regression of Qdiv/Quv to PC3

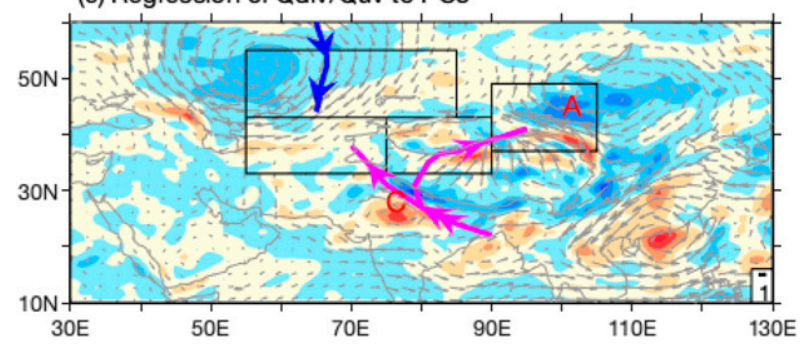

(d) Regression of Qdiv/Quv to PC4

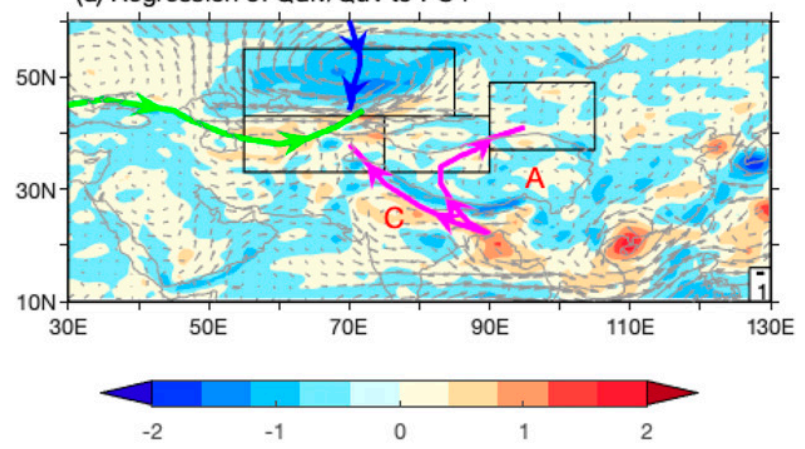

Fig. 4. Regression of the whole level (from the surface to $300 \mathrm{hPa}$ ) water vapor flux (Quv; vectors; $\mathrm{kg} \mathrm{m}^{-1} \mathrm{~s}^{-1}$ ) and water vapor divergence (Qdiv; shading; $10^{-5} \mathrm{~kg} \mathrm{~m}^{-2} \mathrm{~s}^{-1}$ ) to (a)-(d) four types of synoptic circulation. Black boxes are as in Fig. 2. Colored arrows show the water vapor pathways. Black boxes are similar to those in Fig. 3.

(upper-left panel). It also influences the eastern regions of central Asia (upper-right panel). Generally, there are three water vapor branches from the southern boundary that mainly influenced the middle (lower-right panel) and eastern areas of central Asia (upper-right panel) in 2017 and 2019. The first southern branch originates from the Arabian Sea and propagates north and northeast according to the observed results in 2017 and 2019. Another southern branch originates from the Bay of Bengal and northwest transports via the western TP to the northeast, which can be found in the lower-right panel in 2017 and 2019. The last one originates from the Bay of Bengal and propagates to the north and northeast via the eastern TP to the eastern central Asia (upper-right panel) in 2017. The case results further identify the water vapor sources and transport pathways under the four types of synoptic circulation.

The water vapor flux after 2000 and the trends for meridional water vapor flux were further investigated over Asian drylands (Fig. 6a). The water vapor pathways are similar to those under the four types of synoptic patterns. However, by the westerly and in front of the quasi-stationary wave ridge, water vapor enters the Asian drylands from the western and northern boundaries. Three water vapor pathways originate from the Arabian Sea and the Bay of Bengal. One branch transports northwest along the southern flank of the TP and corresponds to the cyclone anomaly over the Indian subcontinent. Another branch via the TP is accompanied by the anomalous west extension of the western Pacific subtropical high that arrives at the east of the TP. In addition, water vapor transport from the Pacific, along with anticyclone flow, also reaches the east of the Asian drylands. Figure 6a also indicates the increase in meridional water vapor flux, where water vapor converges over the Asian drylands and favors more precipitation.

The meridional water vapor pathways of the transient state were also investigated (Fig. 6b). The results show that the meridional water vapor flux in the transient state exhibits an increasing trend with enhanced water vapor transport from the Arabian Sea and the Bay of Bengal. The water vapor pathway in the transient state is the same as the stationary state and the transient term could enhance the impact of the quasistationary term on the net water vapor supply over Asian drylands. The contributions from the transient eddy reinforce the dynamic component over Lake Balkhash and TP, which thereby strengthens meridional wind and meridional water vapor transport.

Considering the wide range of the water vapor transport originating from the Arabian Sea and the Bay of Bengal, the southern boundary water vapor transport along with $30^{\circ}-32^{\circ} \mathrm{N}$ profile was divided into three sections, the western $\left(65^{\circ}-70^{\circ} \mathrm{E}\right)$, middle $\left(75^{\circ}-90^{\circ} \mathrm{E}\right)$, and eastern $\left(95^{\circ}-105^{\circ} \mathrm{E}\right)$ sections. The western section corresponds to the northward water vapor transport originating from the Arabian Sea. The middle section corresponds to the northeast water vapor transport originating from the Arabian Sea, and the westward water vapor transport via the western TP originating from the Bay of Bengal. The eastern section corresponds to the northeast water vapor transport via the eastern TP originating from the Bay of Bengal. In addition, the northern $\left(60^{\circ}-70^{\circ} \mathrm{E}\right.$, along the $52^{\circ}-$ $55^{\circ} \mathrm{N}$ profile $)$ and western $\left(35^{\circ}-50^{\circ} \mathrm{E}\right.$, along the $53^{\circ}-55^{\circ} \mathrm{E}$ profile) boundaries are defined according to the water vapor transport from the Arctic Sea and along the westerly with the anticyclone on the west of the Ural Mountains.

The correlations between the water vapor fluxes in different boundaries and the subregional precipitation are shown in 

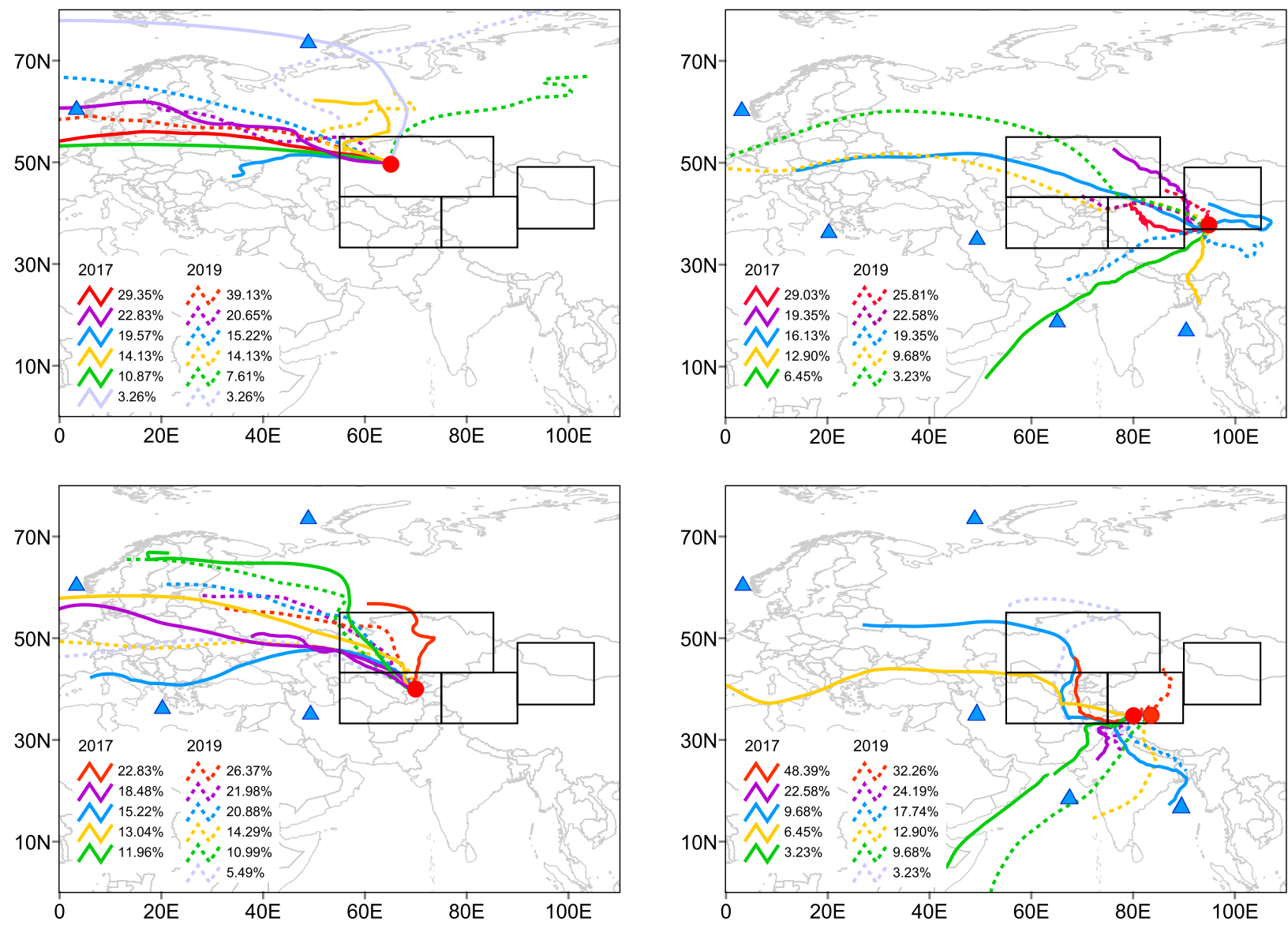

FIG. 5. Pathways and the contribution rates of water vapor transport to the four regions (red points) in the Asian drylands in summer in 2017 and 2019. They are obtained from backward trajectories of water vapor transport from the HYSPLIT model. The triangle represents the possible water vapor source in the most recent 40 years. Black boxes are similar to those in Fig. 3 .

Table 1. The results indicate that except for the eastern subregion in northwest China, water vapor from the north is more positively related to summer precipitation in the Asian drylands, with correlation coefficients higher than 0.4 at a $95 \%$ confidence level. With the exception of the eastern subregion in northwest China and the western subregion in the south of central Asia, water vapor from the middle and eastern sections of the southern boundary are positively related to summer precipitation in the Asian drylands, with correlations higher than 0.33 at a $95 \%$ confidence level. The water vapor from the western boundary is negatively related to summer precipitation in two southern subregions, which suggests that the strong westerly is not favorable for precipitation. The reason for the negative correlation is that the westerly with zonal circulation only leads to weak vertical motion. Conversely, water vapor from the northern and southern boundaries, coupled with high meridional circulation, favors precipitation. Table 1 shows that enhanced southern and northern water vapor transport is more likely to induce increasing precipitation in the Asian drylands. Therefore, more attention should be given to the mechanisms responsible for the variations of water vapor supply.

\section{d. Relation between snow cover over the TP and water vapor in the Asian drylands}

The southern water vapor transport is mainly concentrated around the TP. Due to the complex topography and peculiar location of the periphery of the Asian drylands, the TP has vital terrain effects on the climate via dynamic and thermodynamic processes (Zhang et al. 2018a). Therefore, thermal anomalies over the TP possibly play a critical role in the water vaporrelated circulation and water vapor transport anomalies. The thermodynamic process in the warm season over the TP includes sensible heat flux and latent heat flux. The former dominates the thermodynamic process in the spring and early summer (Zhao et al. 2007), whereas in the midsummer both heat fluxes govern the thermodynamic process. The sensible heat flux relates to precipitation and snow cover and influences soil moisture in cold seasons (Zhang et al. 2018b).

The water vapor flux in summer and its relationship with sensible heat flux over the TP in summer and with the snow cover in spring (May) are illustrated in Fig. 7. There was a significant loss of snow cover over the western TP in May, which was favorable for increasing temperature and diabatic 
(a) Qv trend and 2000-2018 Quv

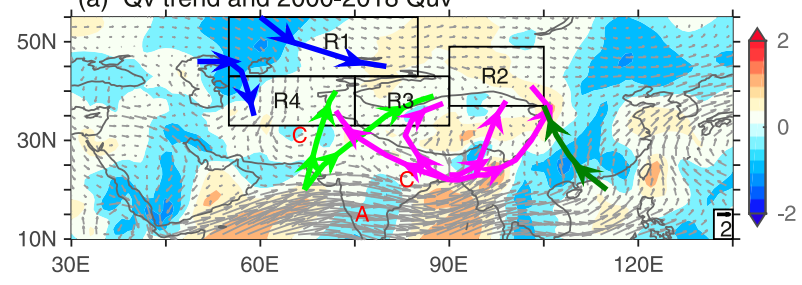

(b) Transient Qv trend and 2000-2018 transient Quv

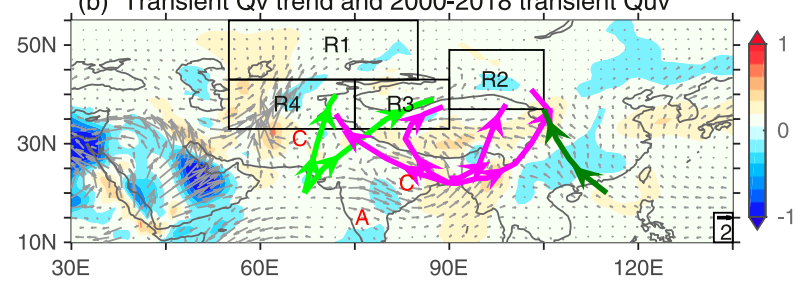

FIG. 6. Composite of (a) the stationary water vapor flux in 2000 18 (vectors; $\mathrm{kg} \mathrm{m}^{-1} \mathrm{~s}^{-1}$ ) and the trend of the meridional water vapor flux (shading; $\times 10^{2}$ ) in summer and (b) the transient water vapor flux and its trend (shading; $\times 10^{2}$ ) in summer. Black boxes are similar to those in Fig. 3, but are marked as R1, R2, R3, and R4.

heating (Zhao and Qian 2007). In addition, diabatic heating could affect simultaneous circulation and precipitation; however, the snow cover in spring could modulate landatmosphere coupling ( $\mathrm{Xu}$ and Dirmeyer 2011) and acts as a subseasonal snow-driven feedback with the atmosphere into summer (Halder and Dirmeyer 2017). The time series of snow cover significantly decreased, with a correlation coefficient of 0.47 at a $95 \%$ significant confidence level. The time series of the water vapor flux from the Arabian Sea showed a significant correlation with the sensible heat flux over the TP (black line; $\left.70^{\circ}-105^{\circ} \mathrm{E}, 28^{\circ}-40^{\circ} \mathrm{N}\right)$. The southern water vapor of the middle section from the Arabian Sea toward the northeast, west, and northwest exhibited decadal variability with a positive trend after 2003. It showed a positive correlation with the sensible heat flux over the TP (black line) of 0.28 at the $90 \%$ confidence level and a negative correlation with the snow cover of the western TP (red line) of -0.33 at the $95 \%$ confidence level. The southern water vapor of the eastern section from the Bay

TABLE 1. Correlations between the total precipitation in summer in the four selected regions (R1, R2, R3, and R4) and the water vapor fluxes $(\mathrm{Qv})$ from the different boundaries. Significant confidence levels above $90 \%$ are marked with an asterisk $(*)$ and above $95 \%$ are marked with two asterisks (**). QuW refers to the west boundary $\left(35^{\circ}-50^{\circ} \mathrm{N}\right.$ along $\left.53^{\circ}-55^{\circ} \mathrm{E}\right)$ and $\mathrm{QvN}$ to the north boundary $\left(60^{\circ}-70^{\circ} \mathrm{E}\right.$ along $\left.52^{\circ}-55^{\circ} \mathrm{N}\right)$. For the south boundary along the $30^{\circ}-32^{\circ} \mathrm{N}$ profile, $\mathrm{QvW}$ is the western section $\left(65^{\circ}-70^{\circ} \mathrm{E}\right)$, QvM the middle section $\left(65^{\circ}-72^{\circ} \mathrm{E}\right)$, and QvE the eastern section $\left(95^{\circ}-105^{\circ} \mathrm{E}\right)$ during $1979-2018$.

\begin{tabular}{lllrrl}
\hline \hline Region & QuW & - QvN & QvW & QvM & QvE \\
\hline R1 & -0.18 & $0.40^{* *}$ & -0.04 & $0.28^{*}$ & $0.41^{* *}$ \\
R2 & -0.16 & 0.13 & 0.15 & -0.01 & $0.28^{*}$ \\
R3 & $-0.46^{* *}$ & $0.36^{*}$ & 0.15 & $0.40^{* *}$ & $0.41^{* *}$ \\
R4 & $-0.39^{*}$ & $0.29 *$ & -0.06 & $0.52^{* *}$ & 0.24 \\
\hline
\end{tabular}

(a) QvW along (60E-70E,30-32N)

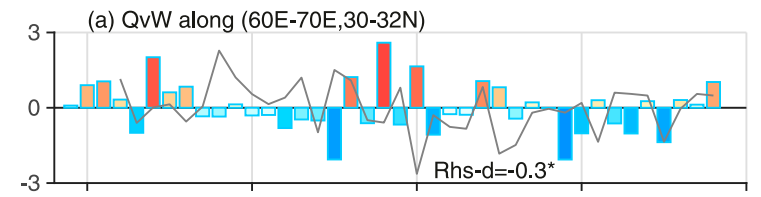

(b) QvM along (75E-90E,30-32N)
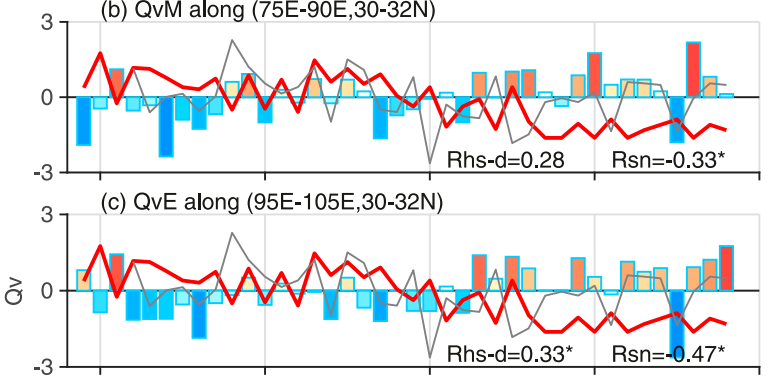

(d) QvN along (60E-70E,52-55N)
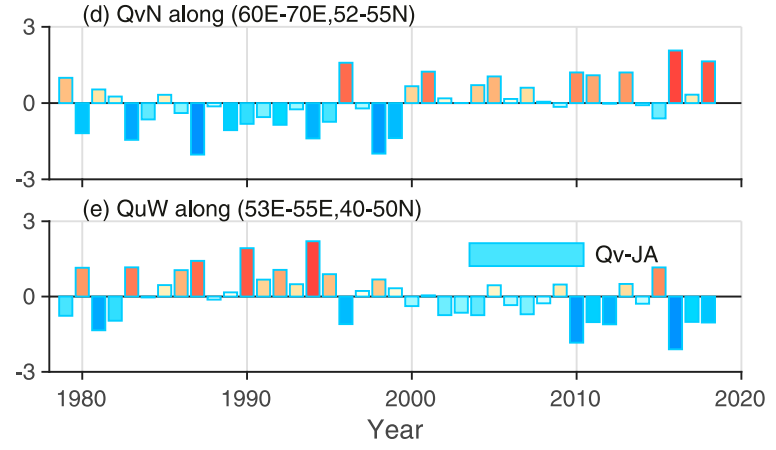

FIG. 7. Time series of the time series of snow cover over the western TP (red line), sensible heat flux of the TP (gray line), the water vapor flux from three southern boundaries $(\mathrm{QvW}, \mathrm{QvM}$, and $\mathrm{QvE})$, the northern boundary (QvN), and the western boundary $(\mathrm{QuW})$. The correlation coefficient of water vapor flux with the sensible heat flux of the TP on the interannual time scale (Rhs-d) and with snow cover over the western TP (Rsn). An asterisk (*) indicates correlations at the $95 \%$ significant confidence levels. The definitions of QvW, QvM, QvE, QvN, and QuW are as in Table 1.

of Bengal toward the northeast exhibited decadal variability with a positive increase after 2003. The positive correlation with the sensible heat flux over the TP (black line) was 0.33 at the $95 \%$ confidence level, and negative correlation with the snow cover of western TP (red line) is -0.47 at the $95 \%$ confidence level. The time series of the water vapor flux from the northern and western boundaries exhibited decadal variation. In general, the decreasing snow cover in the western TP and increasing sensible heat flux over the TP in spring favors water vapor transport from the Arabian Sea and the Bay of Bengal to the Asian drylands.

Meteorological records reveal that the warming rate of the TP is 2 times higher than observed global average over the past five decades (Chen et al. 2015). Under global warming and the interaction between the westerlies and the Asian monsoon, TP snow cover has undergone an abrupt retreat, which endangers the water tower of Asia (Immerzeel et al. 2013). Moreover, besides its direct effect on the snow/ice water resource supply in Asia, the reducing TP snow cover may change the circulation patterns and thereby influence precipitation in Asia as well as 

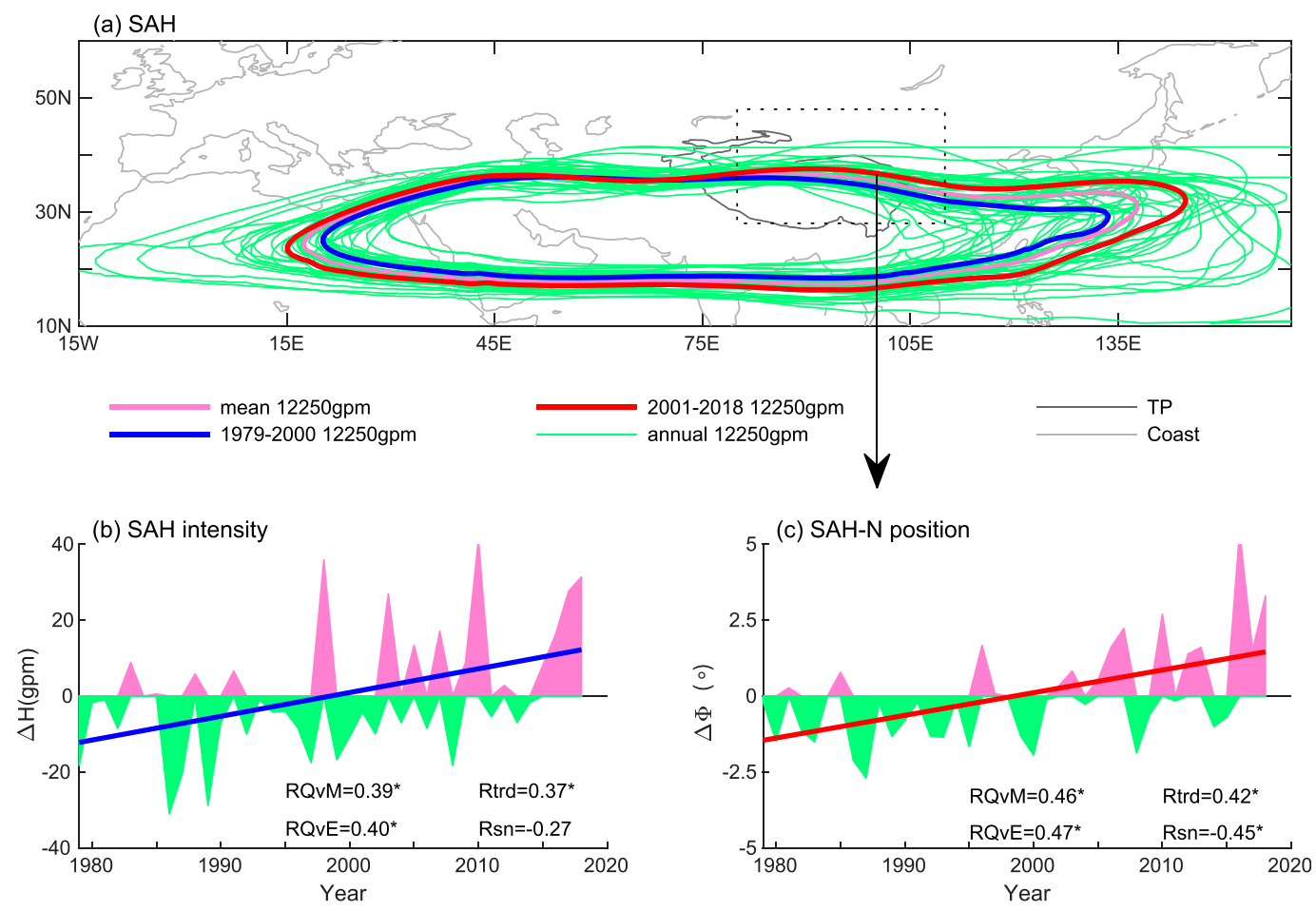

FIG. 8. (a) Annual SAH (green lines) and climatological SAH (pink line) described by 12 250-gpm contour, 19792000 SAH (blue line), and 2001-18 SAH (red line), and the time series of (b) the SAH intensity variation described by the maximum geopotential height (area shading; gpm) and trend (blue line), as well as (c) the northern-edge latitude SAH (area shading) and the trend (red line). Dashed black box in (a) is the selected region for north edge of $\mathrm{SAH}$. The $R$ is the correlation coefficient.

the global climate (Zhang et al. 2018a,b). Therefore, it is important to investigate how the reducing TP snow cover affects the precipitation in Asian drylands through circulations, water vapor, and remote forcing.

\section{e. Effects of snow cover over the TP on precipitation in the Asian drylands}

As reported in previous studies, the TP snow cover anomaly influences the atmospheric circulation over TP and the surrounding regions (Wu et al. 2007; Yang et al. 2011). Zhang et al. (2018b) have shown that the decreased snow cover favors the TP mode of the SAH, with the highest geopotential height center appearing over the TP (defined as TP-SAH). This mode has been proven to be favorable for the water vapor flux from the Arabian Sea to central Asia (Zhao et al. 2014). Moreover, Zhang et al. (2018a) also suggested that the nonuniform zonal warming over TP results in a northward subtropical jet stream and anomalous atmospheric circulation that may affect the precipitation over Asian drylands. To further explore the mechanisms of the water vapor from the Arabian Sea and the Bay of Bengal to the Asian drylands and its relationship with the snow cover over the western $\mathrm{TP}$, the meridional anomalies of the SAH and the subtropical jet stream that form the major upper-level circulation and modulate the low-level circulation around TP were analyzed.

First, the SAH variation and its relationships with the TP snow cover and water vapor flux were investigated to reveal the mechanisms for precipitation changes over Asian drylands. Figure $8 \mathrm{a}$ shows the annual SAH in summer [July-August (JA)] described by 200-hPa, 12 250-gpm climatological SAH, and SAH before and after 2000 . The SAH intensity described by the maximum of $200-\mathrm{hPa}$ geopotential height is shown in Fig. 8 b, while the $\mathrm{SAH}$ position described by the northern edge of the 12 250-gpm line over the north TP is shown in Fig. 8c. It is defined as the latitude position of $12250 \mathrm{gpm}$ at $200 \mathrm{hPa}\left(28^{\circ}-\right.$ $\left.50^{\circ} \mathrm{N}, 80^{\circ}-110^{\circ} \mathrm{E}\right)$. In contrast to the climatological SAH, the SAH before 2000 is smaller than that after 2000. It shows westeast and north-south expansion. The SAH intensity after 2000 is much higher than the average and a positive trend is observed that indicates the strengthening SAH. The correlation coefficient of the SAH intensity with the glacier/snow cover in spring is -0.28 at the $90 \%$ confidence level. The water vapor transport from the middle and eastern sections of the southern boundary shows significant correlation with the SAH intensity at the $95 \%$ confidence level. The aforementioned results indicate that the decreasing snow cover in spring has weak positive effects on the strengthening of SAH.

The SAH's northern edge over TP reflects the north-south extension of the TP-SAH. The SAH was much stronger and with more northward extension after 2000. The correlation coefficient between the SAH northern edge and the snow cover in spring is -0.45 at the $95 \%$ confidence level. The SAH northern edge is also significantly correlated with water vapor 
(a) Jet axis

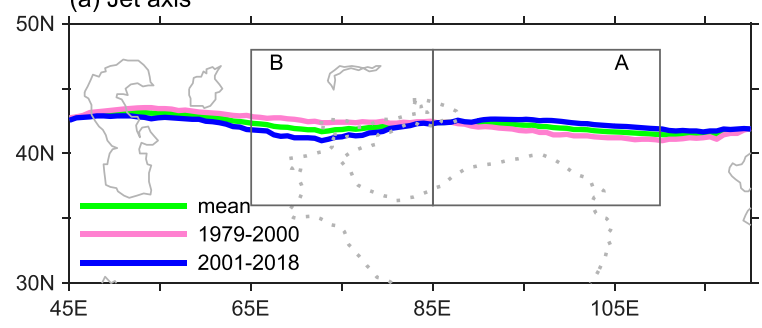

(b) Jet $\mathrm{U}=28 \mathrm{~m} / \mathrm{s}$

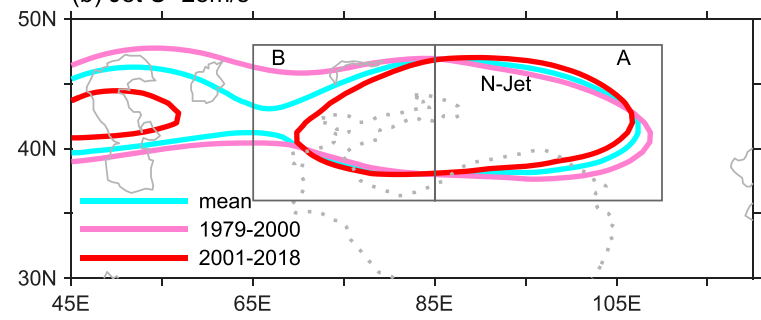

(c) Jet axis (A-B)

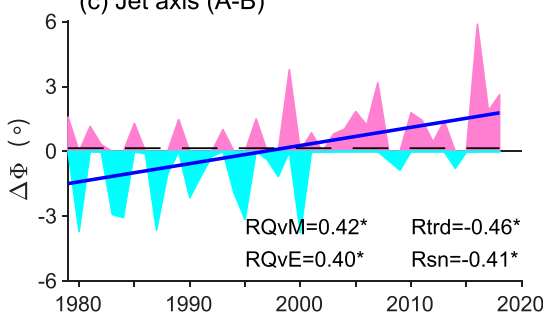

(d) Jet north edge (A-B)

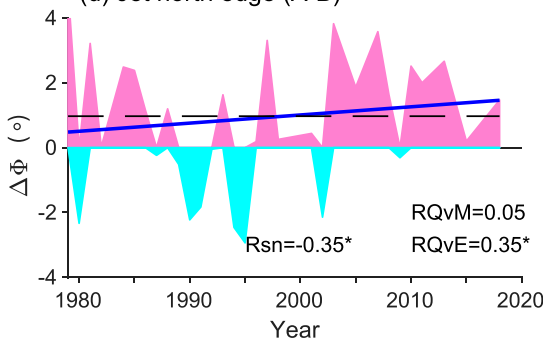

FIG. 9. Latitude position of the (a) climatological Afro-Asian jet axis (green line), 1979-2000 Afro-Asian jet axis (pink line), and 2001-18 Afro-Asian jet axis (blue line). (b) Latitude position of the climatological Afro-Asian jet (cyan line), 1979-2000 Afro-Asian jet (pink line), and 2001-18 Afro-Asian jet (red line) with $U=28 \mathrm{~m} \mathrm{~s}^{-1}$. (c) Time series difference of the Afro-Asian jet axis position (area shading) between the A and B regions. (d) Northern-edge latitude position of the Afro-Asian jet with $U=28 \mathrm{~m} \mathrm{~s}^{-1}$ (area shading) and their trends (blue lines). The $R$ is correlation coefficient.

transport from the middle and east section of the southern boundary, which suggests that the decreasing snow cover in spring has a significant effect on the northern extension in the TP-mode SAH and thereby drives northward water vapor transport.

In contrast with the northern extension of the TP-mode $\mathrm{SAH}$, the Iran-mode SAH with highest geopotential height over the Iranian Plateau only exhibits interannual variation without the northward extending trend. A trough is present between the Iran-mode and the TP-mode SAH that exhibits interannual variation. Zhao et al. (2014) suggested that the Iran-mode SAH modulates the water vapor flux from the Arabian Sea on an interannual time scale. However, the present study found that the northern expansion of the TPmode SAH can modulate the water vapor transport on a decadal scale. Moreover, water vapor has transported from the Arabian Sea toward the northeast, as well as from the Bay of the Bengal toward the west and northwest. The northern expansion of the TP-mode SAH enhances the upper-troposphere divergence that provides a pumping action and results in the enhancement of ascending motion and lower troposphere convergence over central Asia. This not only favors water vapor convergence, but also increases precipitation over the TP and central Asia to the north of the TP. This agrees well with previous studies on precipitation changes over the TP (Gao et al. 2014, 2015).

On the northern flank of the SAH, a subtropical Afro-Asian jet and strong westerly are present that exactly appear over Asian drylands in summer. Thus, the relationship between the jet stream (JS) and the snow cover and TP-mode SAH extension was further investigated. To show the JS anomaly, the latitude position of the JS axis and JS boundary with $U=$ $28 \mathrm{~m} \mathrm{~s}^{-1}$ are shown in Fig. 9. The position changes of the JS before 2000 and after 2000 were also investigated. The results show that the jet stream axis and jet stream northern flank with $U=28 \mathrm{~m} \mathrm{~s}^{-1}$ shift southward between $45^{\circ}$ and $85^{\circ} \mathrm{E}$ but shift northward between $85^{\circ}$ and $110^{\circ} \mathrm{E}$ (Figs. 9a,b), indicating a cyclonic rotation of the Afro-Asian JS.

To describe the cyclonic rotation of JS anomaly (southwestnortheast), the position differences between the eastern (A) and western (B) regions were analyzed. Figure 9c shows the time series difference between the $\mathrm{A}$ and $\mathrm{B}$ regions of the JS axis position. It exhibits an increasing trend that corresponds with the increased northward extension of the eastern section and southward extension of the west section of westerly JS. In addition, the Afro-Asian JS acts as a fundamental waveguide in the midlatitudes (Zhang et al. 2019), where such cyclonic rotation favors the southward cyclone and the northward anticyclone circulation along with the southwestnortheast JS and quasi-stationary wave trough/ridge. The aforementioned strengthens meridional circulation (Gao et al. 2015) and deepens the wave trough around Lake Balkhash. On the one hand, the water vapor transport from the Arabian Sea is strengthened and propagates toward the Asian drylands along with the southwest current in front of the trough. On the other hand, the ascending motion in front of trough lasts for a longer time due to the enhanced meridional circulation and positive vortex advection. Overall, the cyclonic rotation of JS 


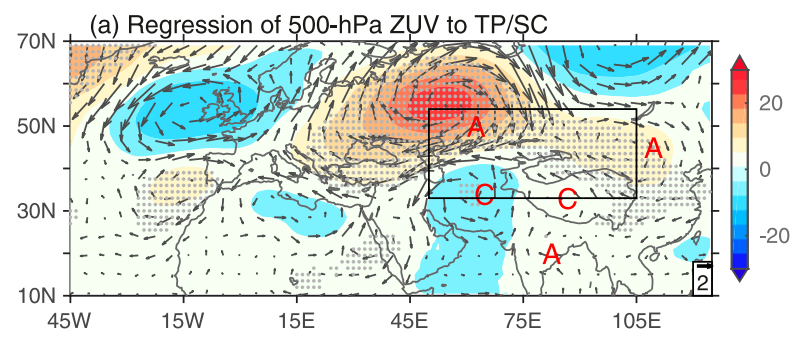

(b) Regression of 500-hPa Qdiv/Quv to TP/SC

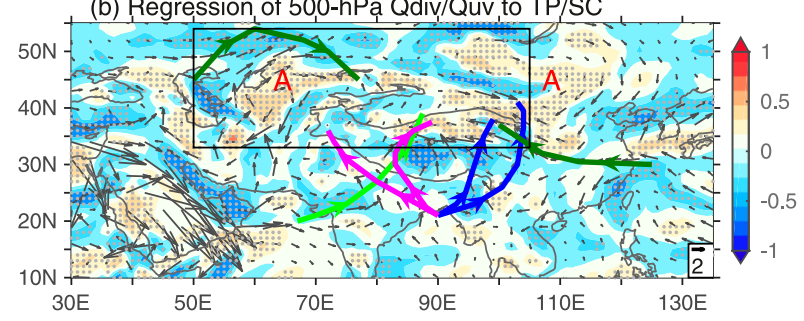

FIG. 10. (a) The regression of the 500-hPa geopotential height (shading; gpm) and wind field (vectors; $\mathrm{m} \mathrm{s}^{-1}$ ) to TP snow cover in spring, and (b) the regression of the total water vapor divergence (shading; $\times-10^{-5} \mathrm{~kg} \mathrm{~m}^{-2} \mathrm{~s}^{-1}$ ) and water vapor (vectors; $\mathrm{kg}$ $\mathrm{m}^{-1} \mathrm{~s}^{-1}$ ) to the TP snow cover (SC) in the spring. Arrow shows the pathway of water vapor transport, and the black box is similar to that in Fig. 2.

anomaly enhances the precipitation in the eastern part of the Asian drylands. Figure $9 \mathrm{~d}$ shows a weak increasing trend of the southwest-northeast JS.

The correlation between the JS and snow cover over the TP in spring indicates that the decreasing TP snow cover favors the cyclonic rotation of the Afro-Asian jet axis (Fig. 9c). The increasing southwest wind favors northward water vapor transport, which is indicated by the significant correlation between the Afro-Asian jet axis index and water vapor flux from the middle and eastern sections of the southern boundary. In addition, the significant correlation between the northern edge of the Afro-Asian jet and the water vapor flux from the eastern section of the south boundary demonstrates the increase in water vapor from the east of the TP and northward of the AfroAsian jet.

The above results indicate that the reduced TP snow cover in spring is favorable for water vapor transport and ascending motion over Asian drylands. To reveal the related circulation and water vapor flux, the geopotential height and wind field at $500 \mathrm{hPa}$, the water vapor flux, and the water vapor divergence are regressed against the TP snow cover (Fig. 10). The results show that an anticyclonic anomaly is present to the west of the Ural Mountains and northwest of Lake Balkhash that is beneficial for the wave ridge around the Ural Mountains, the north wind anomaly in front of the wave ridge, and water vapor transfer from the Caspian Sea, Mediterranean Sea, North Atlantic, and Arctic Ocean. The upstream effects of the enhanced Europe ridge favor the deepening trough over Lake Balkhash manifested by the cyclonic anomaly over Pakistan and further enhance the northward water vapor flux from the Arabian Sea. In addition, a cyclonic anomaly is present over

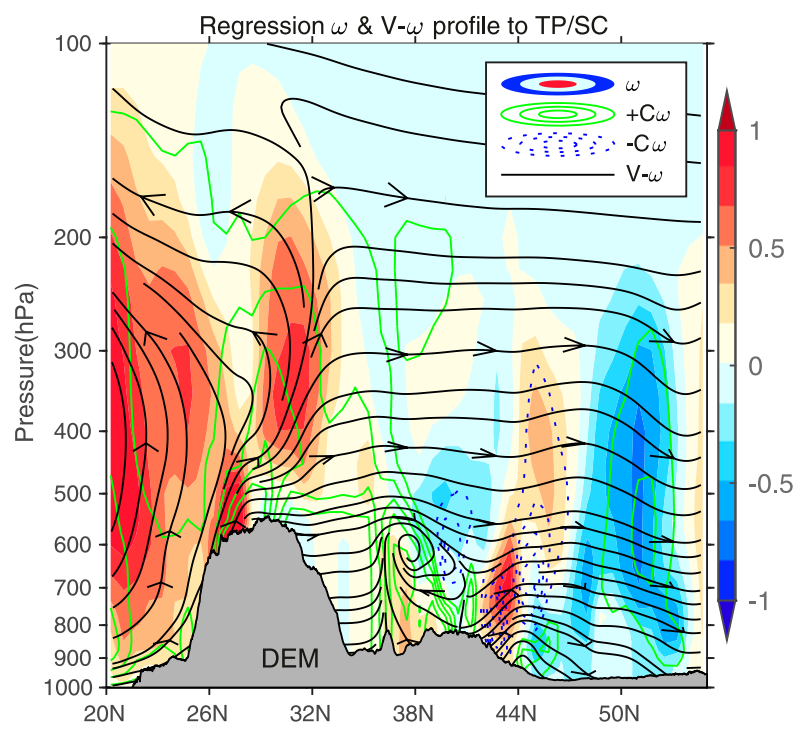

FIG. 11. Regression of vertical velocity $\omega$ (shading; $\times-10^{2} \mathrm{~Pa} \mathrm{~s}^{-1}$ ) along the $80^{\circ}-95^{\circ} \mathrm{E}$ profile and $V-\omega$ cross section (streamline) to the TP snow cover (SC) in late spring, in contrast to the climatological vertical velocity $(C \omega$; green line is positive, blue dashed line is negative; $\left.\times-10^{2} \mathrm{~Pa} \mathrm{~s}^{-1}\right)$. Gray background shows the topography from the DEM data.

the western TP and an anticyclonic anomaly over the east of the Indian subcontinent, which promote the water vapor transport from the Arabian Sea and the Bay of Bengal to the Asian drylands. An anticyclonic anomaly is present in the northeast of the TP indicating northwest extension of the western Pacific subtropical high and leading to water vapor transport from the Pacific.

Figure 11 shows the regression of the vertical velocity $(-\omega)$ and $V$ wind cross section along the $80^{\circ}-95^{\circ} \mathrm{E}$ profile to the TP snow cover, and the climatological vertical velocity is plotted for contrast. The results show an increased ascending motion between $20^{\circ}$ and $38^{\circ} \mathrm{N}$ below $300 \mathrm{hPa}$ in response to the reduced TP snow cover. Its center over TP shows a northward ascending motion with the positive center of the vertical velocity on the north flank of the climatological positive center $(-\omega)$, which favors northward precipitation belts. The $V-\omega$ cross section shows an enhanced south wind from $20^{\circ}$ to $55^{\circ} \mathrm{N}$ along with reduced TP snow cover, which is favorable for northward water vapor transport. In summary, both ascending motion and south wind anomalies are beneficial to northward precipitation.

\section{f. Simulation of TP snow cover effect on precipitation in the Asian drylands}

To prove the TP snow cover effect on precipitation in the Asian drylands, we perform a sensitivity experiment that decreases $30 \%$ of TP snow cover over the western $\mathrm{TP}\left(70^{\circ}-90^{\circ} \mathrm{E}\right.$, $\left.31^{\circ}-41^{\circ} \mathrm{N}\right)$ by removing those with lower snow depth from April to June. The Afro-Asian jet, SAH, precipitation rate, and meridional water vapor flux in control and sensitivity simulations are contrasted. Figure 12a shows that with the reduced TP 

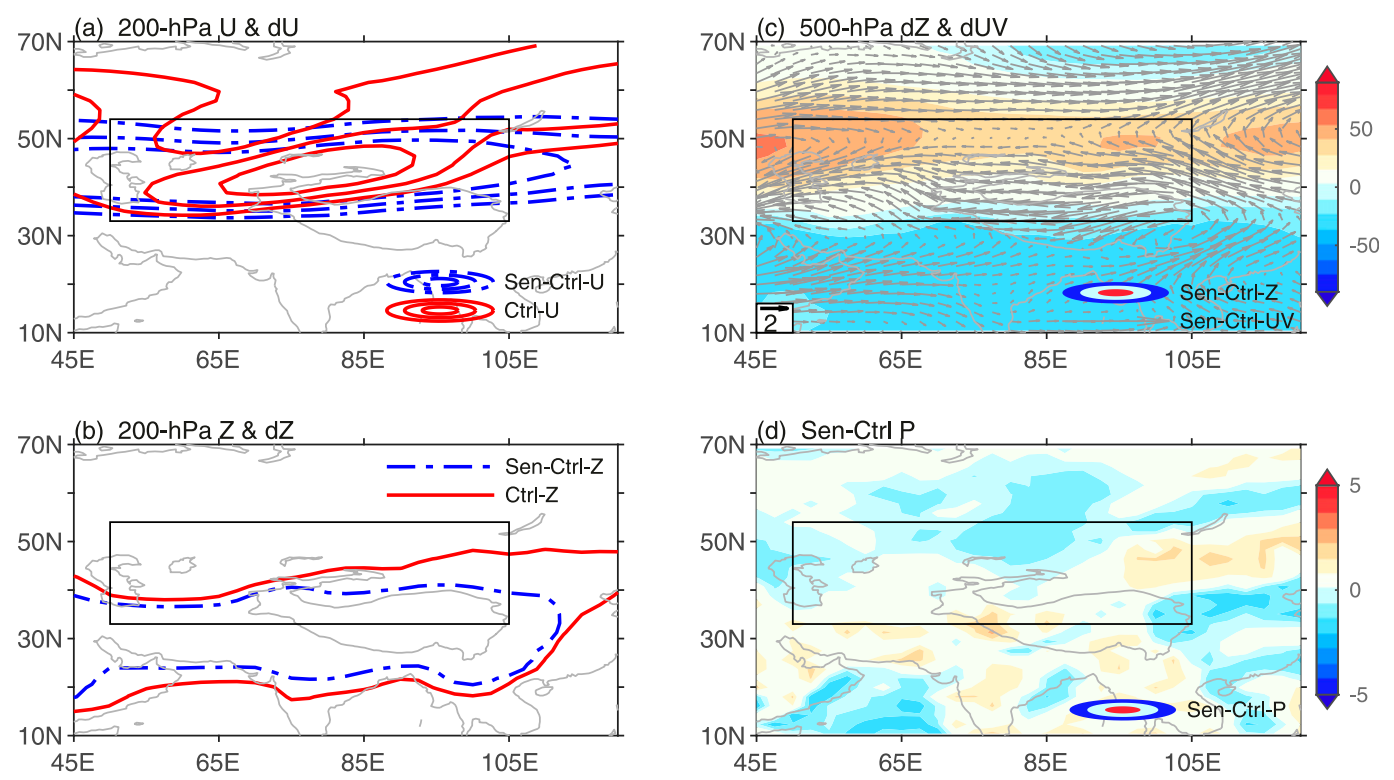

(e) Sen-Ctrl variable

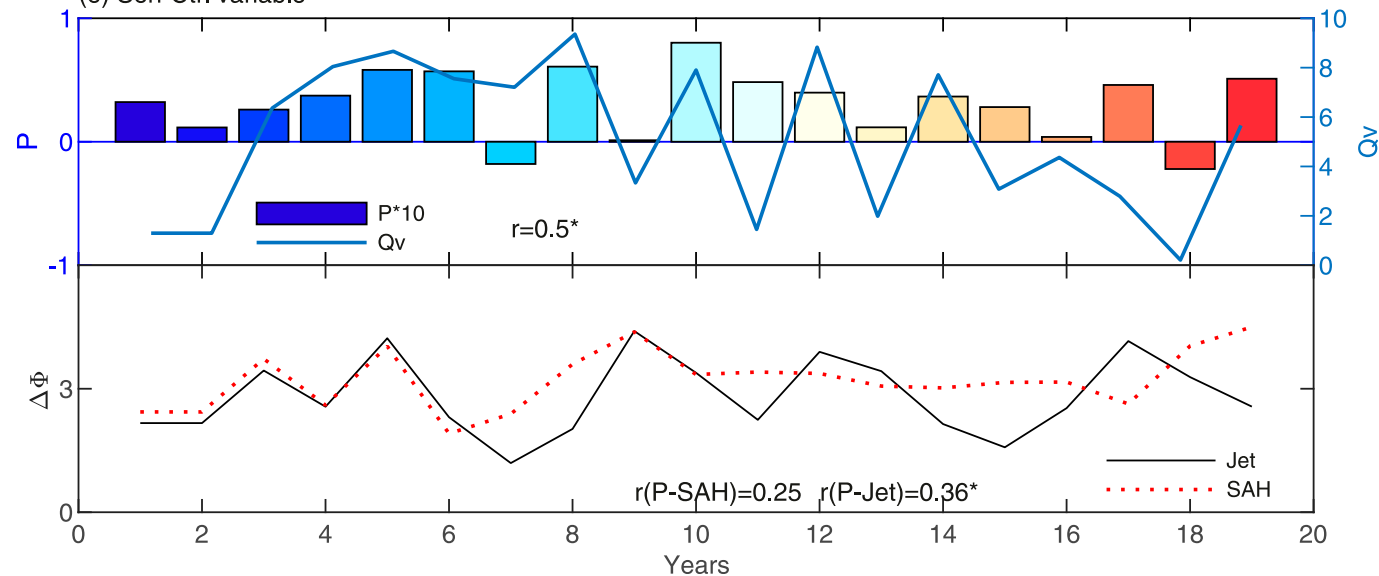

FIG. 12. (a) Simulation of decreasing in $30 \%$ of TP snow cover (Sen. - Ctrl; i.e., sensitivity minus control) and contrast of $U=15,20,25$ in control (blue) and sensitivity (red) simulation (line; $\mathrm{m} \mathrm{s}^{-1}$ ). (b) The 200-hPa SAH with $Z=12600 \mathrm{gpm}$ in control (red) and sensitivity (blue) simulation (contour). (c) The 500-hPa geopotential height (shading; gpm) and $U$ and $V$ wind velocity $\left(\mathrm{m} \mathrm{s}^{-1}\right)$. (d) Precipitation (mm day ${ }^{-1}$ ) from CESM. The Sen. - Ctrl. variables are precipitation rate $\left(\mathrm{mm} \mathrm{day}^{-1}\right)$, transient meridional water vapor flux $\left(\times 0.1 \mathrm{~kg} \mathrm{~m}^{-1} \mathrm{~s}^{-1}\right)$, meridional shift of SAH, and jet position $\left({ }^{\circ} \mathrm{N}\right)$.

snow cover, the Afro-Asian jet shifts northward exhibited by an anomalous $U$ wind with $U=15,20$, and $25 \mathrm{~m} \mathrm{~s}^{-1}$ and cyclonic rotation of the Afro-Asian jet. Figure $12 \mathrm{~b}$ shows a northward shift of SAH with the northward 200-hPa 12600gpm contour. Both the upper-troposphere SAH and Afro-Asian jet are favorable for increasing south wind and northward divergence, which further enhances the lower-level convergence. The 500-hPa geopotential height and wind field (Fig. 12c) indicate the enhanced European anticyclone, the Ural anticyclone, the trough over Balkhash Lake in the midlatitudes, and the cyclone anomaly over the Arabian Sea and Indo-China as well as south of the TP, which enhances the south wind and water vapor flux toward central Asia. Enhancing water vapor and ascending motion could increase precipitation, as seen from the positive anomaly of precipitation in Fig. 12d. Through eddy-driven and wave-flow interaction, the anomaly of the quasi-stationary wave is beneficial to the northward westerly jet and the effect of the SAH. Figure 12e shows variable anomalies due to reducing snow cover. Apart from two years, the precipitation rate is positive, and the other three variables, namely the SAH, jet stream, and meridional water vapor flux, are all positive. The correlation coefficients between the precipitation rate and jet and meridional water vapor flux were significant at $90 \%$ confidence level. The simulation results identify the increasing precipitation due to TP snow cover. They also show decreasing zonal wind over Asian drylands and 


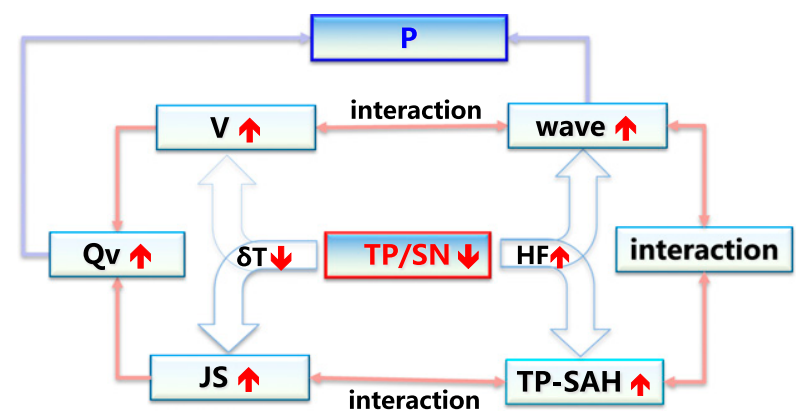

FIG. 13. Schematic diagram summarizing two physical processes for the TP glacier/snow cover (TP/SC): 1) the effect on the meridional water vapor flux $(\mathrm{Qv})$ through the meridional wind $V$ and subtropical jet stream (JS) and the zonal temperature gradient $\delta T$, and 2) the effect on the wave trough/ridge through the TP mode of the South Asian high (TP-SAH), due to increasing diabatic heating (HF) and the contribution to precipitation $P$ in the Asian drylands.

the widened Afro-Asian jet belt, which are the possible mechanisms related to reducing snow cover that need more investigation.

Besides increasing runoff that provides water for the Asian drylands, the simulation results support the hypothesis that the increasing precipitation in Asian drylands is also related to the reduced snow cover over TP. With global warming, the reducing snow cover reaches approximately $15 \%$ and will continue to decrease in the future (Qiu 2012). Therefore, the reducing snow cover could govern increasing precipitation trends of drylands in the context of global warming. The above simulation also reveals the possible variability of an increasingly warm and wet central Asia on a multidecadal time scale, which is directly related to decreasing snow cover and climate warming. A warming and wetting of central Asia also appeared during the periods of 2.2$1.8 \mathrm{ka}$ BP (Yang et al. 2004), 40-30 ka BP (Shi and Yu 2003), and 1550-1840 AD (Chen et al. 2009). It can effectively explain the water vapor history in those warmer, wetter periods, which is out of phase with that in monsoonal Asia (F. Chen et al. 2008).

\section{Summary and discussion}

Drylands face the threat of water shortage, particularly under the conditions of rapid warming that leads to high evaporation and water loss. Precipitation and runoff provide the critical water supply, control the water balance, and influence dryland development. Therefore, this study explored precipitation variation beyond the interannual time scale and the possible mechanisms in Asian drylands in order to further evaluate future water balance and social development.

This study suggests that in addition to the influence of the large topography, such as the Tianshan Mountains, the TP, and the Pamir Plateau, large-scale circulation drives the increasing precipitation in Asian drylands. Circulation anomalies can be categorized into two groups. First, the deepening trough over Lake Balkhash not only benefits the low-level cyclone in front of the trough and further facilitates ascending motion, but also favors water vapor transport from the Arabian Sea toward
Asian drylands. Second, the anomalous cyclonic circulation over TP and anticyclonic circulation over the Indian subcontinent, as well as the deepening trough over Lake Balkhash, benefit the water vapor transport from the Arabian Sea and the Bay of Bengal via the TP toward the Asian drylands. The upper-level northward shift in the SAH and Afro-Asian jet with enhanced upper divergence and the vertical and horizontal shear strengthen the lower-level convergence and ascending motion. These physical processes increase the precipitation in the Asian drylands. The mechanism is illustrated in Fig. 13.

The circulation and water vapor flux anomalies correspond to the anomalous snow cover over the TP in the late spring, which decreased in the western TP in the early twenty-first century. Soil water storage has been found to retain the effects of the snow cover forcing into succeeding months, and it gives rise to water vapor and circulation anomalies in the summer within a seasonal time scale (Zhao et al. 2007; Zhao et al. 2012). Reduced snow cover decreases soil moisture and increases diabatic heating, including sensible heat flux and latent heat flux, over the TP. These effects benefit the enhanced TP-mode SAH and contribute to the lower-level convergence over the TP. In addition, the reduced TP snow cover increases TP surface temperature and decreases the thermal contrast between the TP and the Indian Ocean SST, which favors the northward shift in TP-mode SAH and subtropical circulation. The TP thermal anomaly also affects the midlatitude stationary wave trains and surface temperature via eddy and temperature gradients (Zhao et al. 2007). According to Senan et al. (2016), the northward westerly jet and the enhanced south wind guide the northward shift of the lower-level convergence (Fig. 13) and the water vapor flux from the Arabian Sea and the Bay of Bengal.

In addition to the reduced TP snow cover, Arctic ice loss likely relates to the increasing precipitation in Asian drylands. The deepening of the Lake Balkhash trough is linked with the enhancement of the stationary wave (Petoukhov et al. 2016), which is suggested to correlate with the Arctic ice loss and Arctic amplitude (Francis and Vavrus 2012).

Acknowledgments. This research was jointly supported by the National Key R\&D Program of China (Grant 2018YFC1507101), the National Natural Science Foundation of China (Grant 41975083), and Distinguished Young Scientists (Grant 41625019).

\section{REFERENCES}

Andrews, D. G., 2010: An Introduction to Atmospheric Physics. 2nd ed. Cambridge University Press, 237 pp.

Baldwin, J., and G. Vecchi, 2016: Influence of the Tian Shan on arid extratropical Asia. J. Climate, 29, 5741-5762, https://doi.org/ 10.1175/JCLI-D-15-0490.1.

Barnett, T. P., J. C. Adam, and D. P. Lettenmaier, 2005: Potential impacts of a warming climate on water availability in snowdominated regions. Nature, 438, 303-309, https://doi.org/ 10.1038/nature04141.

Bothe, O., K. Fraedrich, and X. Zhu, 2012: Precipitation climate of Central Asia and the large-scale atmospheric circulation. Theor. Appl. Climatol., 108, 345-354, https://doi.org/10.1007/ s00704-011-0537-2. 
Chen, D. L., and Coauthors, 2015: Assessment of past, present and future environmental changes on the Tibetan Plateau. Chin. Sci. Bull., 60, 3025-3035.

Chen, F., and J. Chen, 2012: A discussion on the westerlydominated climate model in mid-latitude Asia during the modern interglacial period. Earth Sci. Front., 279-280, 86-87, https://doi.org/10.1016/j.quaint.2012.07.381.

— Central Asia and its out-of-phase relationship with Asian monsoon history. Quat. Sci. Rev., 27, 351-364, https://doi.org/ 10.1016/J.QUASCIREV.2007.10.017.

Chen, J., F. Chen, E. Zhang, J. B. Stephen, A. Zhou, and W. Zhang, 2009: A 1000-year chironomid-based salinity reconstruction from varved sediments of Sugan Lake, Qaidam Basin, arid Northwest China, and its palaeoclimatic significance. Chin. Sci. Bull., 54, 3749-3759, https://doi.org/10.1007/s11434-009-0201-8.

Chen, M. Y., W. Shi, P. Xie, V. Silva, V. Kousky, R. Higgins, and J. Janowiak, 2008: Assessing objective techniques for gaugebased analyses of global daily precipitation. J. Geophys. Res., 113, D04110, https://doi.org/10.1029/2007JD009132.

Chen, Y., H. Deng, B. Li, L. Zhi, and C. Xu, 2014: Abrupt change of temperature and precipitation extremes in the arid region of Northwest China. Quat. Int., 336, 35-43, https://doi.org/ 10.1016/j.quaint.2013.12.057.

— W. Wi, H. Deng, G. Fang, and Z. Li, 2016: Changes in Central Asia's water tower: Past, present and future. Sci. Rep., 6, 35458, https://doi.org/10.1038/srep35458.

Christian, D., 2000: Silk roads or steppe roads? The silk roads in world history. J. World Hist., 11 (1), 1-26, https://doi.org/ 10.1353/jwh.2000.0004.

Dee, D. P., and Coauthors, 2011: The ERA-Interim reanalysis: Configuration and performance of the data assimilation system. Quart. J. Roy. Meteor. Soc., 137, 553-597, https://doi.org/ 10.1002/qj.828.

Deng, H., Y. Chen, H. Wang, and S. Zhang, 2015: Climate change with elevation and its potential impact on water resources in the Tianshan mountains, Central Asia. Global Planet. Change, 135, 28-37, https://doi.org/10.1016/j.gloplacha.2015.09.015.

Ding, Q., and B. Wang, 2005: Circumglobal teleconnection in the Northern Hemisphere summer. J. Climate, 18, 3483-3503, https://doi.org/10.1175/JCLI3473.1.

Douville, H., A. Ribes, B. Decharme, R. Alkama, and J. Sheffield, 2013: Anthropogenic influence on multi-decadal changes in reconstructed global evapotranspiration. Nat. Climate Change, 3, 59-62, https://doi.org/10.1038/NCLIMATE1632.

Enomoto, T., 2004: Interannual variability of the Bonin high associated with the propagation of Rossby waves along the Asian jet. J. Meteor. Soc. Japan, 82, 1019-1034, https://doi.org/ 10.2151/jmsj.2004.1019.

Estilow, T. W., A. H. Young, and D. A. Robinson, 2015: A longterm Northern Hemisphere snow cover extent data record for climate studies and monitoring. Earth Syst. Sci. Data, 7, 137142, https://doi.org/10.5194/essd-7-137-2015.

Frachetti, M. D., C. E. Smith, C. M. Traub, and T. Williams, 2017: Nomadic ecology shaped the highland geography of Asia's silk roads. Nature, 543, 193-198, https://doi.org/10.1038/nature21696.

Francis, J. A., and S. J. Vavrus, 2012: Evidence linking Arctic amplification to extreme weather in mid-latitudes. Geophys. Res. Lett., 39, L06801, https://doi.org/10.1029/2012GL051000.

Gao, Y., L. Cuo, and Y. Zhang, 2014: Changes in moisture flux over the Tibetan Plateau during 1979-2011 and possible mechanisms. J. Climate, 27, 1876-1893, https://doi.org/10.1175/JCLID-13-00321.1.
Gao Y., L. R. Leung, Y. Zhang, and L. Cuo, 2015: Changes in moisture flux over the Tibetan Plateau during 1979-2011: Insights from the high resolution simulation. J. Climate, 28, 4185-4197, https://doi.org/10.1175/JCLI-D-14-00581.1.

Gerlitz, L., E. Steirou, C. Schneider, V. Moron, S. Vorogushyn, and B. Merz, 2019: Variability of the cold season climate in Central Asia. Part II: Hydroclimatic predictability. J. Climate, 32, 6015-6033, https://doi.org/10.1175/JCLI-D-18-0892.1..

Hagg, W., L. N. Braun, M. Kuhn, and T. I. Nesgaard, 2007: Modelling of hydrological response to climate change in glacierized Central Asian catchments. J. Hydrol., 332, 40-53, https://doi.org/10.1016/j.jhydrol.2006.06.021.

Halder, S., and P. A. Dirmeyer, 2017: Relation of Eurasian snow cover and Indian summer monsoon rainfall: Importance of the delayed hydrological effect. J. Climate, 29, 1273-1289, https:// doi.org/10.1175/JCLI-D-16-0033.1.

Hodges, K. I., R. W. Lee, and L. Bengtsson, 2011: A comparison of extratropical cyclones in recent reanalyses ERA-Interim, NASA MERRA, NCEP CFSR, and JRA-25. J. Climate, 24, 4888-4906, https://doi.org/10.1175/2011JCLI4097.1.

Hong, B., and Coauthors, 2014: Increasing summer rainfall in arid eastern-central Asia over the past 8500 years. Sci. Rep., 4, 5279, https://doi.org/10.1038/srep05279.

Howard, K. W. F., and K. K. Howard, 2016: The new "Silk Road economic belt" as a threat to the sustainable management of central Asia's transboundary water resources. Environ. Earth Sci., 75, 976, https://doi.org/10.1007/s12665-016-5752-9.

Huang, J., H. Yu, X. Guan, G. Wang, and R. Guo, 2016: Accelerated dryland expansion under climate change. Nat. Climate Change, 6, 166-171, https://doi.org/10.1038/nclimate2837.

,,-- A. Dai, Y. Wei, and L. Kang, 2017: Drylands face potential threat under $2^{\circ} \mathrm{C}$ global warming target. Nat. Climate Change, 7, 417-422, https://doi.org/10.1038/nclimate3275.

Huang, W., F. Chen, S. Feng, J. Chen, and X. Zhang, 2013: Interannual precipitation variations in the mid-latitude Asia and their association with large-scale atmospheric circulation. Chin. Sci. Bull., 58, 3962-3968, https://doi.org/10.1007/s11434013-5970-4.

, S. Feng, J. Chen, and F. Chen, 2015: Physical mechanisms of summer precipitation variations in the Tarim Basin in northwestern China. J. Climate, 28, 3579-3591, https://doi.org/ 10.1175/JCLI-D-14-00395.1.

—, X. He, Z. Yang, T. Qiu, J. S. Wright, B. Wang, and D. Lin, 2018: Moisture sources for wintertime extreme precipitation events over South China during 1979-2013. J. Geophys. Res. Atmos., 123, 6690-6712, https://doi.org/10.1029/2018JD028485.

Hurrell, J. W., M. M. Holland, and P. R. Gent, 2013: The Community Earth System Model: A framework for collaborative research. Bull. Amer. Meteor. Soc., 94, 1339-1360, https://doi.org/10.1175/BAMS-D-12-00121.1.

Huss, M., and R. Hock, 2018: Global-scale hydrological response to future glacier mass loss. Nat. Climate Change, 8, 135-140, https://doi.org/10.1038/s41558-017-0049-x.

Immerzeel, W. W., F. Pellicciotti, and M. F. P. Bierkens, 2013: Rising river flows throughout the twenty-first century in two Himalayan glacierized watersheds. Nat. Geosci., 6, 742-745, https://doi.org/10.1038/ngeo1896.

Jiang, J., T. Zhou, X. Chen, and L. Zhang, 2020: Future changes in precipitation over Central Asia based on CMIP6 projections. Environ. Res. Lett., 15, 054009, https://doi.org/10.1088/1748-9326/ab7d03.

Karl, T. R., and K. E. Trenberth, 2003: Modern global climate change. Science, 302, 1719-1723, https://doi.org/10.1126/ science.1090228. 
Li, X., G. Cheng, Y. Ge, H. Li, F. Han, and X. Hu, 2018: Hydrological cycle in the Heihe River basin and its implication for water resource management in endorheic basins. J. Geophys. Res. Atmos., 123, 890-914, https://doi.org/10.1002/ 2017JD027889.

Li, Z., Y. Chen, G. Fang, and Y. Li, 2017: Multivariate assessment and attribution of droughts in central Asia. Sci. Rep., 7, 1316, https://doi.org/10.1038/s41598-017-01473-1.

Lim, Y.-K., 2015: The east Atlantic/West Russia (EA/WR) teleconnection in the North Atlantic: Climate impact and relation to Rossby wave propagation. Climate Dyn., 44, 3211-3222, https://doi.org/10.1007/s00382-014-2381-4.

— , and H.-D. Kim, 2013: Impact of the dominant large-scale teleconnections on winter temperature variability over East Asia. J. Geophys. Res. Atmos., 118, 7835-7848, https://doi.org/ 10.1002/jgrd.50462.

Linderholm, H. W., T. Ou, J. H. Jeong, C. K. Folland, D. Gong, H. Liu, Y. Liu, and D. Chen, 2011: Interannual teleconnections between the summer North Atlantic Oscillation and the East Asian summer monsoon. J. Geophys. Res., 116, D13107, https://doi.org/10.1029/2010JD015235.

Lioubimtseva, E., and G. M. Henebry, 2009: Climate and environmental change in arid central Asia: Impacts, vulnerability, and adaptations. J. Arid Environ., 73, 963-977, https://doi.org/ 10.1016/j.jaridenv.2009.04.022.

Liu, Y. Y., L. Wang, W. Zhou, and W. Chen, 2014: Three Eurasian teleconnection patterns: Spatial structures, temporal variability, and associated winter climate anomalies. Climate Dyn., 42, 2817-2839, https://doi.org/10.1007/s00382-014-2163-z.

Minobe, S., 1997: A 50-70 year climatic oscillation over the North Pacific and North America. Geophys. Res. Lett., 24, 683-686, https://doi.org/10.1029/97GL00504.

Okumura, Y., S. P. Xie, A. Numaguti, and Y. Tanimoto, 2001: Tropical Atlantic air-sea interaction and its influence on the NAO. Geophys. Res. Lett., 28, 1507-1510, https://doi.org/ 10.1029/2000GL012565.

Petoukhov, V., S. Petri, S. Rahmstorf, D. Coumou, K. Kornhuber, and H. J. Schellnhuber, 2016: Role of quasiresonant planetary wave dynamics in recent boreal spring-to-autumn extreme events. Proc. Natl. Acad. Sci. USA, 113, 6862-6867, https:// doi.org/10.1073/pnas.1606300113.

Pritchard, H. D., 2019: Asia's shrinking glaciers protect large populations from drought stress. Nature, 569, 649-654, https:// doi.org/10.1038/s41586-019-1240-1.

Qiu, J., 2012: Tibetan glaciers shrinking rapidly: Comprehensive survey reveals influence of prevailing winds. Nature, https:// doi.org/10.1038/nature.2012.11010.

Romatschke, U., and R. A. Houze, 2011: Characteristics of precipitating convective systems in the South Asian monsoon. J. Hydrometeor., 12, 3-26, https://doi.org/10.1175/2010JHM1289.1.

Rosenberg, N. J., M. S. Mckenney, and P. Martin, 1989: Evapotranspiration in a greenhouse-warmed world: A review and a simulation. Agric. For. Meteor., 47, 303-320, https:// doi.org/10.1016/0168-1923(89)90102-0.

Safriel, U., 2009: Deserts and desertification: Challenges but also opportunities. Land Degrad. Dev., 20,353-366, https://doi.org/ 10.1002/ldr.935.

Schiemann, R., D. Lüthi, and C. Schär, 2009: Seasonality and interannual variability of the westerly jet in the Tibetan Plateau region. J. Climate, 22, 2940-2957, https://doi.org/10.1175/ 2008JCLI2625.1.

Senan, R., and Coauthors, 2016: Impact of springtime HimalayanTibetan Plateau snowpack on the onset of the Indian summer monsoon in coupled seasonal forecasts. Climate Dyn., 47, 2709-2725, https://doi.org/10.1007/s00382-016-2993-y.

Shi, Y., and G. Yu, 2003: Warm-humid climate and transgressions during 40-30 ka B.P. and their potential mechanisms. Quat. Sci., 23 (1), 1-11.

— , and Coauthors, 2003: Discussion on the present climate change from warm-dry to warm-wet in Northwest China (in Chinese). Quat. Sci., 25, 152-164.

Sodemann, H., C. Schwierz, and H. Wernli, 2008: Interannual variability of Greenland winter precipitation sources: Lagrangian moisture diagnostic and North Atlantic Oscillation influence. J. Geophys. Res., 113, D03107, https://doi.org/10.1029/2007JD008503.

Sorg, A., T. Bolch, M. Stoffel, O. Solomina, and M. Beniston, 2012: Climate change impacts on glaciers and runoff in Tian Shan (Central Asia). Nat. Climate Change, 2, 725-731, https:// doi.org/10.1038/nclimate1592.

Stein, A. F., R. R. Draxler, G. D. Rolph, B. J. B. Stunder, M. D. Cohen, and F. Ngan, 2015: NOAA's HYSPLIT atmospheric transport and dispersion modeling system. Bull. Amer. Meteor. Soc., 96, 2059-2077, https://doi.org/10.1175/BAMS-D14-00110.1.

Wan, W., and Coauthors, 2016: A lake data set for the Tibetan Plateau from the 1960s, 2005, and 2014. Sci. Data, 3, 160039, https://doi.org/10.1038/sdata.2016.39.

Wang, H., T. Gao, and L. Xie, 2018: Extreme precipitation events during 1960-2011 for the northwest China: Space-time changes and possible causes. Theor. Appl. Climatol., 137, 977995, https://doi.org/10.1007/s00704-018-2645-8; Corrigendum, 137, 997-999, https://doi.org/10.1007/s00704-018-2668-1.

Wang, W., and D. Zhang, 2019: Holocene vegetation evolution and climatic dynamics inferred from an ombrotrophic peat sequence in the southern Altai Mountains within China. Global Planet. Change, 179, 10-22, https://doi.org/10.1016/j.gloplacha.2019.05.003.

$\mathrm{Wu}, \mathrm{G}$., and Coauthors, 2007: The influence of mechanical and thermal forcing by the Tibetan Plateau on Asian climate. J. Hydrometeor., 8, 770-789, https://doi.org/10.1175/JHM609.1.

Xie, P. P., A. Yatagai, M. Y. Chen, T. Hayasaka, Y. Fukushima, C. M. Liu, and S. Yang, 2007: A gauge-based analysis of daily precipitation over East Asia. J. Hydrometeor., 8, 607-626, https://doi.org/10.1175/JHM583.1.

Xie, S.-P., C. Deser, G. A. Vecchi, J. Ma, H. Teng, and A. T. Wittenberg, 2010: Global warming pattern formation: Sea surface temperature and rainfall. J. Climate, 23, 966-986, https://doi.org/10.1175/2009JCLI3329.1.

Xu, C. C., J. X. Li, and J. Zhao, 2015: Climate variations in northern Xinjiang of China over the past 50 years under global warming. Quat. Int., 358, 83-92, https://doi.org/10.1016/j.quaint.2014.10.025.

Xu, L., and P. Dirmeyer, 2011: Snow-atmosphere coupling strength in a global atmospheric model. Geophys. Res. Lett., 38, L13401, https://doi.org/10.1029/2011GL048049.

Xue, L., B. Zhu, C. Yang, G. Wei, X. Meng, A. Long, and G. Yang, 2017: Study on the characteristics of future precipitation in response to external changes over arid and humid basins. Sci. Rep., 7, 15148, https://doi.org/10.1038/s41598-017-15511-5.

Yang, B., A. Braeuning, Y. Shi, and F. Chen, 2004: Evidence for a late Holocene warm and humid climate period and environmental characteristics in the arid zones of northwest China during 2.2-1.8 kyr BP. J. Geophys. Res. Atmos., 109, D02105, https://doi.org/10.1029/2003JD003787.

Yang, K., X. Guo, J. He, J. Qin, and T. Koike, 2011: On the climatology and trend of the atmospheric heat source over the Tibetan Plateau: An experiments-supported revisit. J. Climate, 24, 1525-1541, https://doi.org/10.1175/2010JCLI3848.1. 
Yao, J., Y. Chen, Y. Zhang, and X. Yu, 2018: Hydroclimatic changes of Lake Bosten in northwest China during the last decades. Sci. Rep., 8, 9118, https://doi.org/10.1038/s41598-01827466-2.

Yao, T., and Coauthors, 2019: Recent Third Pole's rapid warming accompanies cryospheric melt and water cycle intensification and interactions between monsoon and environment: Multidisciplinary approach with observation, modeling, and analysis. Bull. Amer. Meteor. Soc., 100, 424-444, https://doi.org/ 10.1175/BAMS-D-17-0057.1.

Yatagai, A., 2003: Evaluation of hydrological balance and its variability in arid and semi-arid regions of Eurasia from ECMWF 15 years reanalysis. Hydrol. Processes, 17, 2871-2884, https:// doi.org/10.1002/hyp.1439.

Zhang, J., Q. Tang, H. Chen, and S. Liu, 2017: Northward shift in circulation system over the Asian mid-latitudes linked to an increasing heating anomaly over the northern Tibetan Plateau during the past two decades. Int. J. Climatol., 37, 834-848, https://doi.org/10.1002/joc.4743.

- H. Hen, and Z. Wu, 2018a: Double-mode adjustment of Tibetan Plateau heating to the summer circumglobal teleconnection in the Northern Hemisphere. Int. J. Climatol., 38, 663-676, https://doi.org/10.1002/joc.5201.

- C. Liu, and H. Chen, 2018b: The modulation of Tibetan Plateau heating on the multi-scale northernmost margin activity of East Asia summer monsoon in northern China. Global Planet. Change, 161, 149-161, https://doi.org/10.1016/ j.gloplacha.2017.12.011.

, Z. Chen, H. Chen, Q. Ma, and A. Teshome, 2020: North Atlantic multidecadal variability enhancing decadal extra- tropical extremes in boreal late summer in the early twentyfirst century. J. Climate, 33, 6047-6064, https://doi.org/10.1175/ JCLI-D-19-0536.1.

Zhang, M., Q. Ren, X. Wei, J. Wang, X. Yang, and Z. Jiang, 2011: Climate change, glacier melting and streamflow in the Niyang River basin, southeast Tibet, China. Ecohydrology, 4, 288298, https://doi.org/10.1002/eco.206.

-, Y. Chen, Y. Shen, and Y. Li, 2017: Changes of precipitation extremes in arid Central Asia. Quat. Int., 436, 16-27, https:// doi.org/10.1016/j.quaint.2016.12.024.

- _ _ _ _ a a nd B. Li, 2019: Tracking climate change in Central Asia through temperature and precipitation extremes. J. Geogr. Sci., 29, 3-28, https://doi.org/10.1007/s11442-0191581-6.

Zhao, H., B. Xu, T. Yao, G. Wu, S. Lin, J. Gao, and M. Wang, 2012: Deuterium excess record in a southern Tibetan ice core and its potential climatic implications. Climate Dyn., 38, 1791-1803, https://doi.org/10.1007/s00382-011-1161-7.

Zhao, P., Z. Zhou, and J. Liu, 2007: Variability of Tibetan spring snow and its associations with the hemispheric extratropical circulation and East Asian summer monsoon rainfall: An observational investigation. J. Climate, 20, 3942-3955, https:// doi.org/10.1175/JCLI4205.1.

Zhao, Y., and Y. F. Qian, 2007: Relationship between the surface thermal anomalies in the Tibetan Plateau and the rainfall in the Jianghuai area in summer. Chin. J. Atmos. Sci., 1, 145-154. , and Coauthors, 2014: Impact of the middle and upper tropospheric cooling over central Asia on the summer rainfall in the Tarim Basin, China. J. Climate, 27, 4721-4732, https:// doi.org/10.1175/JCLI-D-13-00456.1. 